This PDF is a selection from an out-of-print volume from the National Bureau of Economic Research

Volume Title: National Product, War and Prewar

Volume Author/Editor: Simon Kuznets

Volume Publisher: NBER

Volume ISBN: 0-87014-332-8

Volume URL: http://www.nber.org/books/kuzn44-1

Publication Date: February 1944

Chapter Title: National Product, War and Prewar

Chapter Author: Simon Kuznets

Chapter URL: http://www.nber.org/chapters/c9340

Chapter pages in book: (p. 1 - 56) 


\title{
NATIONAL PRODUCT
}

\section{WAR AND PREWAR}

\author{
SIMON KUZNETS
}

OUR ECONOMYIN WAR

Occasional Paper 17: February 1944

NATIONAL BUREAU OF ECONOMIC RESEARCH, INC.

1819 Broadway, New York 23, N. Y. 
The author gratefully acknowledges the assistance of Frederick M. Cone and Jacob Grauman of the War Production Board in the preparation of this paper.

This PAMPhLet has been produced in full compliance with all government regulations for the conservation of paper, metal, and other essential materials.

COPYRGGT, 1944, BY THE NATIONAL BUREAU OF ECONOMIC RESEARCH, INC.

1819 BROADWAY, NEW YORK 23, N. Y. ALL RIGHTS RESERVED 


\section{THE WARTIME CONCEPT}

National income or net national product measures the contribution of the productive system to the basic purpose economic activity is assumed to satisfy. In peacetime this purpose is to provide for the population's needs; and the contribution of economic activity is represented by: (a) flow of goods to ultimate consumers (consumers' outlay); (b) net additions to stocks of goods that have not yet reached consumers but are intended to be used, directly or indirectly, to satisfy ultimate wants (net capital formation). National income totals, however derived, equal the sum of these two components.

For short term changes it is often preferable to study gross rather than net additions to fixed equipment and construction. To estimate the current consumption of these durable capital goods, as we must in order to pass from gross to net additions, is difficult and the results are subject to a wide margin of error. In business judgments the line between net addition to durable equipment or construction and replacement is tenuous. Hence, many studies of the national product, especially those related to capital formation, use also a total that differs from national income in that it includes gross rather than net additions to durable equipment and construction. Designated gross national product, it exceeds net national product or national income by the amount of current consumption (depreciation and depletion) of durable capital goods.

In a major war, economic activity has a second basic purpose: to provide commodities and services for the armed conflict. It is not realistic to treat this conflict as a production or consumption process subordinate to that of satisfying needs of ultimate consumers; nor is it valid to assume that even in an all-out war, civilian needs become completely subordinate to military (so that, for example, population groups that cannot contribute to the war are deprived of all economic goods). Both basic purposes must be met and decisions concerning the allocation of resources between the two depend chiefly upon factors outside the ordinary economic processes of the market place. In a nonmilitaristic country the emergence of the armed conflict as a new channel of final use, affecting a large proportion of resources, calls for a concept of national product that in essence is noncomparable with that of peacetime. 1

The composition of this wartime concept of the national product

1 The conceptual problems involved will be discussed more explicitly in another paper now in preparation. 
can be clearly seen by analogy with the peacetime. The armed conflict as a channel of final use gives rise to a new category similar to the flow of goods to consumers - the flow into the armed conflict, representing the value of equipment for and services of the armed forces. So far as new plants or construction units are built for the production of munitions or the training of troops, the net addition should enter the wartime concept of net national product and the gross addition, gross national product. The wartime national income total then includes four distinct components: (a) flow of goods to consumers, (b) net capital formation, nonwar, (c) flow of finished war products, (d) net additions to durable equipment and construction designed specifically for the production of war products. The gross national product in wartime differs from the net total just described in that it includes gross rather than net additions to all durable equipraent and construction, in both the nonwar and war sectors. In actual statistical practice, however, components (c) and (d) are lumped under total war outlay, either including or excluding depreciation on war construction."

\section{TOTALS IN CURRENT PRICES}

The estimates in Table 1 are merely approximations to the national product totals as defined above because the usable data are not sufficiently detailed to measure accurately end-product categories. The

2 The concepts used here differ from those of the Department of Commerce which have wide currency. The Department's gross national product assumes that all government expenditures represent final products, whereas we retain the assumption adopted in prewar estimates, viz., that taxes paid by business enterprises (excluding the rise caused by the war) represent services by government to business and, therefore, intermediate rather than final products. Consequently, the Department's gross national product totals in current prices are larger than ours.

Its national income totals are made up of income payments to individuals and net savings of corporations after all tax payments. Our totals, on the source of paymeats approach, would be approximated by income payments to individuals and corporate net savings gross of the increase in corporate taxes in years of war and of prewar defense programs.

In formulating the concept of gross national product no good reason was seen for modifying the assumption that some part of government services is an intermediate sather than a final product; or for deviating from the somewhat arbitrary but customary assumption which measures these intermediate services by peacetime paynents of corporate tares. In defining national income or net national product, it was considered indispensable to retain its meaning as the sum of all net finished output; i.e., in wartime as the sum of flow to consumers, net nonwar capital formation, and net war production. On a payment level, this calls for the inclusion, in addition to corporate net savings, of the increase in corporate taxes. Compensation of such productive factors as is represented by income payments is measured (by the Depirtment also) inclusive of the larger direct tax payments; compensation of the factor of enterprise, represented by net corporate savings, should likewise be measured inclusive of the increase in corporate taxes. 
following comments serve to indicate the respects in which the estimates fail to give what is wanted.

TABLE 1

Derivation of National Product Totals, Wartime Concept, 1939-1943

(billions of dollars)

\begin{tabular}{|c|c|c|c|c|c|}
\hline (Dillions or dol & 1939 & 1940 & 1941 & 1942 & $\begin{array}{c}1943 \\
1 s t \\
\text { Half } \\
\text { (annual } \\
\text { rate) }\end{array}$ \\
\hline Flow of goods to consumers (excl. direct taxes) & 61.7 & 65.7 & 74.6 & 82.0 & $\mathbf{8 9 . 7}$ \\
\hline Value of direct gov. services & 3.1 & 3.1 & 3.1 & 3.1 & 3.1 \\
\hline Total flow to consumers $(1+2)$ & 64.8 & 68.3 & $\mathbf{7 7 . 7}$ & 85.1 & 92.8 \\
\hline mation, private & 4.7 & 8.3 & 12.1 & 0.2 & -8.7 \\
\hline ion, public, & 1.3 & 0.9 & 1.0 & 0.3 & -0.4 \\
\hline $\begin{array}{l}\text { Total net capital formation, nor } \\
\text { War outlay (excl. depreciation o }\end{array}$ & 6.0 & 9.2 & 13.1 & 0.5 & -9.1 \\
\hline or net nation & 1.4 & 2.7 & 12.2 & 48.0 & 78.9 \\
\hline & 72.2 & 80.7 & 103.0 & 133.6 & 162.6 \\
\hline & 7 & 7.4 & 7.9 & 8.8 & 9.0 \\
\hline & neglig & gib & 0.3 & 1.3 & 2.1 \\
\hline & 79.48 & 88.1 & 111.2 & 143.7 & 173.7 \\
\hline
\end{tabular}

Line 1: Survey of Current Business, Aug. 1943, p. 13, Table 3, line 16, and p. 12, Table 1, line 14.

Line 2: An average of direct personal taxes for 1936-38. Figures from Survey, May 1942, p. 12, Table 4, line 10.

Line 4: Gross private capital formation (Survey, Aug. 1943, p. 13, Table 5, line 8, and p. 12, Table 1, line 9) minus depreciation and depletion (ibid., p. 12, Table 4, line 3).

Line 5: Nonwar public construction gross, minus estimated depreciation of $\$ 1$ billion foreach year. For 1939, the figures for gross are from Survey, Feb. 1942, p. 36, Table 15 -all public excl. residential, military and naval, and factory; for 1940-42, ibid., Jan. 1943, p. 11, Table 11-all public exd. residential, military and naval, and nonresidential industrial; for first half of 1943 , direct from Dept. of Commerce, same categories.

Line 7: From Swrvey, Aug. 1943, p. 13, Table 5, line 4, and p. 12, Table 1, line 4.

Line 9: Private depreciation and depletion (Survey, Aug. 1943, p. 12, Table 4, line 3) plus $\$ 1$ billion for public nonwar.

Line 10: A 10\% depreciation charge on a cumulative total of government-financed war construction. This depreciation ratio is a fairly crude approximation.

The value of finished commodities and services flowing to (or retained from their production by) households and consuming institutions (line 1) excludes subsistence and related expenditures by the government for the armed forces. Theoretically, it should include them, since it should measure all goods flowing to consumers qua consumers. There is no more reason to exclude the value of subsistence for the armed services from the flow to consumers (as a measure of a distinct category of final products) because it is covered in war outlay than to exclude expenditures on consumer goods by workers in munitions plants. The subsistence item under war outlay is, together with pay, a measure of the value of services rendered by 
the military forces; the value of the goods involved is part of the flow of final consumer products from the productive system.

However, there is considerable difficulty in measuring this item. It should include only the part of the allowance for food, clothing, shelter, etc., that is a minimum needed by the armed forces as peacetime consumers; not the part that represents special needs arising from the particular demands of military activity. Yet the breakdown of total expenditures on food, clothing, shelter, transportation, etc. for the armed forces between a peacetime consumption minimum and the special military needs is difficult. It may be argued that since the compensation of the armed forces is an arbitrarily determined quantity, a simpler assumption would be to equate it to money payments alone, thereby allowing in war outlay for the consumers' expenditures of the armed forces. But this would seriously undervalue the services of the armed forces, calling for a subsequent correction, and mis-classify under war outlay a part of the flow of goods to consumers. It was deemed preferable to characterize the omission as a qualification upon our estimates of the flow of goods to consumers. Could this item be included, both flow to consumers and national product in a year like 1942 would be $\$ 2$ to $\$ 3$ billion larger than the totals in Table $1 .^{3}$

Line 1 fails also to include services to individuals by governments. In peacetime these services were assumed, somewhat arbitrarily, to be valued at the amount of direct personal taxes paid by individuals. There is no reason to modify the assumption in wartime: at least prewar direct tax payments may still be interpreted as compensation for services by governments to individuals, and only the increase in direct taxes attributed to the additional needs due to war. For this reason, prewar direct taxes (line 2) are added to round out consumers' expenditures to total outlay (line 3 ). ${ }^{4}$

The two items of capital formation described as nonwar (lines 4 and 5) raise immediately the problem of distinguishing between war and nonwar capital goods. Some part of the addition to privately

3 If we assume minimum subsistence at $\$ 00$ per member of the armed forces, and an average of 4 million in the armed forces in 1942, the item amounts to $\$ 2$ billion. It would tend to rise rapidly from 1941 to 1943 , accentuating the rise shown in Table 1. 1 It may be argued that a more reasonable estimate would be to allow for an increase in direct taxes associated with the rising cost per unit of government services. This correc. tion, however, would be minor in comparison with the major categories involved; and would call for a subsequent adjustment of the current dollar totals by a price index for government services. In the calculations to derive totals in 1939 prices, direct taxes were held constant at the 1939 price level, with the implicit assumption that the real volume of services to consumers did not change. 
financed equipment and construction was, during the years covered in Table 1, specifically designed for the production of war implements or their components; and a substantial proportion of both private and public nonwar capital formation, while not immediately directed at the output of munitions, was due to the expansion of activity associated with the war. In a sense, all capital formation in a period of intensive preparation for or participation in a major war is for military purposes, stimulated in the short run by war needs.

Yet the classification cannot be based upon purposes-for they are intangible. It must rather take into account the extent to which equipment and construction are either of such physical character as to be suitable only for war production in the narrowest sense or of such extraordinary size as can be warranted by war demands alone and in no way be justified by reasonable estimates of peacetime needs. But this basis cannot be clearly established with the present data; and the best practicable criterion is the source of financing. Additions to capital equipment that are specifically for transient war needs and are so unwarranted by peacetime prospects as to require government financing could be defined as capital formation for war purposes. Private financing or government financing outside the war budget was considered as evidence that the capital formation involved could be defined as nonwar in the longer run.

War outlay (line 7) differs from the usual measure in the exclusion of payments that do not represent a draft upon real resources (property purchase, prepayments, and the like); and of depreciation on government-financed war construction and equipment. Neither adjustment can be statistically precise. But it seemed better to attempt an adjustment than to accept total disbursements classified by the Treasury under the war account as the value of war production.

Another disadvantage of the estimates of war outlay is that they usually measure war production at some point before it reaches the units that dispose of it for purposes of war. Even in the series for munitions, products accepted by the military agencies and ready for combat or training use are combined with products still subject to further modification. While no duplication is involved, war outlay is not as clearly a fully finished products total as is the flow of goods to ultimate consumers.

The above qualifications stem from a single cause: the available information is on categories of outlay by source, which is not an unambiguous guide to the categories of final products. Yet the dis- 
parities between what we wish and can measure are not sufficient to bar significant analysis.

Table 1 reveals the marked changes in national product and in its composition-the striking rise in the total in current dollars from 1939 to 1943; the spectacular climb of war outlay to stellar levels and high proportions of total product; the rise in nonwar capital formation until 1941 and the subsequent drastic contraction; the impressive increase in consumers' expenditures, retarded after 1941.

However, there is little purpose in analyzing here the estimates in Table 1. Our interest is in real output and the relative proportions of its components measured in real terms; and from this viewpoint Table 1 may be quite misleading. Even in peacetime, current dollar values tend to disguise movements in real output and contain some elements of noncomparability in the price structure and the price movements of different components of the national product. But these elements of noncomparability and heterogeneity are few in peacetime because price changes and shifts are usually not violent. In wartime, however, prices tend to move violently and bases of valuation for the war and nonwar sectors of the economy are inherently noncomparable. Current dollar estimates are then merely a first step toward estimates of real output and its components. The next step is obviously to measure price changes and differentials.

\section{PRICE CHANGES AND dIFFERENTIALS: THE PROBLEM}

To express national product totals, derived as sums of final output components, each valued at changing price levels and on bases possibly different from one component to another, as internally consistent magnitudes unaffected by temporal changes in prices we have to have indexes designed to adjust totals in current prices for both price changes and differentials.

We begin by assuming that the valuation base current in recent prewar years for nonwar products is appropriate for deriving national product totals in real terms comparable as between prewar and war years. The alternative would be to accept the valuation base in the war production sector in war years and try to modify the base in the nonwar sectors; so that each part of total national product would be valued just as war goods are valued. The difficulty of so translating all components of national product to the unusual and rapidly shifting valuation base that determines the pricing of war goods is obvious. But regardless of it, an attempt to get comparable and inter- 
nally consistent national product totals covering both prewar and war years should preferably employ prewar valuation bases: they are more persistent in the longer run and provide a more familiar set of values for appraising changes during the war.

If this preference is conceded, the task in the nonwar sector is reduced to finding reliable measures of changes in prices over time. Formidable difficulties arise even here. The available price indexes fail to reflect fully qualitative deterioration in commodities and services; the 'pricing up' that takes the form of adding superficial and unwanted elements to the good, largely in order to raise it into higher price brackets withput violating price regulations; the reduction in discounts or in services formerly granted in connection with durable commodities; pricing on the black markets; and the general effects of narrowing freedom of choice on the part of would-be civilian purchasers. As the description below of the procedures indicates, only a few halting steps can be taken toward overcoming these difficulties. But for the nonwar sector we can derive indexes of final product prices which, when applied to current price totals, will yield approximate estimates of the relevant components of the national product as categories of final output measured at prewar market values.

The war sector presents much greater difficulties. To begin with, prices of final products (various items of munitions and of war construction) are not freely accessible; nor are they in existence during the full period spanning both prewar and war years, for the obvious reason that many of the items were not produced until the country was well into the war. Even when items produced in 1939-40 and 1942-43 are superficially similar, e.g., war planes, certain types of guns, and merchant ships, the qualitative change is such that the resemblance is more in name than in substance. It is impossible to derive directly a price index of war products that would span both prewar and war years.

Even were it possible, a major aspect of the difficulty would still remain-price and valuation bases for the war and nonwar sectors would still not be comparable; or, following the preference just indicated-it would still be difficult to put prices of war products on a valuation base comparable to that which determines prices of peacetime goods on the free markets of the economy. The difficulty is of considerable quantitative import, because commodities and services

3 With the conclusion of the war, new nonwar bases may be used, preferably of a post. war year free from the disturbing effects of war. 
for use in the armed conflict are purchased under conditions radically different from those that govern peacetime products in the market place. Consequently, even if we expressed war outlay as totals at constant prices of munitions, war construction, and nonmunitions, the valuation of at least the first two components would be quite different from that of peacetime goods; and we would be adding into national product physical quantities weighted by a heterogeneous set of weights.

It may be argued that the rather lavish use of monetary incentives and of legal measures distinguishing the valuation of war products in wartime from that of products in peacetime markets represents a shift in consumer preferences on a par with changes in more normal times; or that it represents a mere quantitative expansion of the area of governmental purchasing and government-destined production, which in peacetime also is characterized by valuation rules substantially different from those of the competitive markets of the economy. To the first argument one may reply that if there are such violent and drastic shifts in consumer preference, continuous and comparable measures of national product cease to have any meaning unless based on a relatively fixed set of values that consciously ignores such shifts. $A$ reply to the second argument is that while government-bound production and products of the private business system are not valued on comparable bases in peacetime, the former is so small in years of peace that the consequent distortion in the national product totals may be neglected; but that the matter cannot be dismissed so lightly when the government-controlled sector becomes as large as it does during a major war. ${ }^{B}$ At any rate, it seemed preferable to wrestle with the problem than to dispose of it summarily; or reduce it to a question of temporal changes only in final product prices in the war outlay sector.

The attempt being made here is, then, to value war output not at actual 1939 prices (if such could be found), but at prices it would have fetched in 1939 had it been produced under conditions com. parable to peacetime; and in circumstances where producers could attain the efficiency of resource-input characteristic of comparable peacetime industries grown to maturity without the urgent haste and

If after this war the scope of government-controlled activity extends and continues to be conditioned by rules quite different from those of the private market place, the prob. lem raised here will remain formidable and will require careful reconsideration of the somewhat arbitrary compromises made in estimating national product for this country
before this war. 
waste of wartime. The concept may at first seem unrealistic; but it is only so far as any application of peacetime criteria to wartime is unrealistic. And if we are to have national product totals continuous and comparable as between prewar and war years, and if we are to have some basis for evaluating war production in its longer range postwar aspect, we cannot avoid introducing arbitrarily a common base.

In this attempt we must begin with evaluation at the level of resource-input. At the level of final products there is no comparability between peacetime goods and war implements, between pastry and machine guns. The choice between the two does not take place in the way consumers choose among various final goods; or in the way producers choose among capital goods in response to consumers' choices of final products. But resources common to both pastry and machine guns can be identified; and some can be specifically tagged as having been used to produce the former in a year of peace and the latter in a year of war. It is thus at the level of resource-input that the first step can be taken to reduce elements of heterogeneity (at a point of time ) and noncomparability (over time) in the wartime national product totals in current prices.

The element of beterogeneity in total national product in wartime is this: identical or comparable resources utilized at a given time for different ends (e.g., civilian and war production) are compensated at different monetary rates, but the differences in compensation do not correspond to differences in the efficiency of use. The elements of noncomparability with prewar years (or during the war itself) are: (i) identical or comparable resources in identical or comparable uses are compensated at different monetary rates; (ii) identical or comparable resources shifting to different uses (e.g., from peace to war production) are compensated at different monetary rates, but the differences in compensation do not correspond to differences in the efficiency of use.

Therefore measuring war (and hence total) output in real terms raises two distinct questions: (i) What changes occur over time in the monetary compensation of identical or comparable resources? (ii) Does a change from peace to war production mean that identical or comparable units of productive resources are more or less efficient? This separation of two elements in the problem is artificial in that the resources that shift to new uses undergo changes both in monetary compensation per efficiency unit and in efficiency. But for purposes 
of measurement it is best to deal with them separately. As the first is clearly much more susceptible to definition and measurement, it can be treated first, while the second is disregarded for the time being. When the first has been dealt with, the relative efficiency of resourceinput in war outlay is considered, largely with the help of tentative, alternative assumptions.

With the aim indicated, the successive steps are: (i) To measure changes over time in final product prices for goods included under flow to consumers, nonwar capital formation, and certain parts of war outlay (nonmunitions) (Sec. 4a). (ii) To measure changes in prices of resources entering the major part of war outlay (munitions and war construction) (Sec. 4a). (iii) To assume changes in the efficiency of resource-input in the nonwar sectors and nonmunitions; thus to convert the indexes derived under (i) to indexes of the compensation of resources, which makes it possible to translate national product and its components to the level of resource-input at 1939 resource prices (Sec. 4b). (iv) To assume changes in and the relative levels of the efficiency of resource-input in munitions and war construction, and to convert the indexes under (ii) to indexes of the final prices of munitions and war construction, prices on a base identical with peacetime prices of products of comparable industries. With the price differentials between peace and war goods eliminated, national product and its components can be translated to a consistent level of final output, at 1939 prices (Sec. 4c).

\section{PRICE CHANGES AND diffERENTIALS:}

\section{PROCEDURES AND ASSUMPTIONS}

\section{a Price Indexes for Products and Resources}

The extent to which price and other data can be made to reflect quality and quantity changes in the nonwar sector, and differences in the productivity of resources between the nonwar and war sectors, determines the meaning of the totals in constant prices as measures of the national product and its components in real terms. While the procedures are described in detail in the Appendix, a brief statement is a necessary background for grasping the meaning of the estimates.

To test the adequacy of the existing price indexes, used by the Department of Commerce to translate consumers' outlay into constant prices, we compared movements in 'deflated' totals with changes in production destined for civilian use; and reviewed the scope of the price data to see if it was possible to extend their application and 
bring their weights into closer correspondence with the subtotals of consumers' outlay in current prices. The first test was applied to food products and apparel (clothing and shoes); the second to the price index used to 'deflate' consumers' outlay on services. In both a substantial correction for the understatement of the existing price indexes (in this particular use) seemed warranted. In all other commodity groups and for some sectors of the service group, the available and customarily used price data could not be adjusted, although they are commonly acknowledged to reflect but poorly the types of price change briefly indicated in the opening paragraphs of Section 3. As a result, even the over-all price indexes derived here for the flow of goods to consumers probably understate the price rise that occurred; and the price-adjusted totals, therefore, overstate the increase or understate the decline in the 'real' volume of consumer goods.

The price indexes for nonwar capital formation used by the Department of Commerce were accepted, representing as they do the most practicably complete utilization of available data on product prices. In this group also restrictions and a smaller supply have led to a quality deterioration of the products; reduction of discounts and services that were customary in more normal times; and a narrowing of the freedom of the would-be buyer's choice. There is, therefore, ground for assuming that here also the price indexes understate the full extent of the price rise; and that, consequently, the totals adjusted for price changes are overstatements of volumes in constant prices.

In the treatment of war outlay nonmunitions were separated from munitions and war construction. The former comprise military pay and subsistence allowances; civilian pay in war agencies; subsistence outlays, including clothing and personal equipment as well as travel for the armed forces; agricultural exports to allies; and similar miscellaneous items. The price indexes for the commodity parts of the category were based on Bureau of Labor Statistics wholesale price data; for pay items, on known changes in rates of pay. The estimates are rather crude, but contain no perceptible biases.

Munitions and war construction comprise planes, guns, ammunition, naval ships, merchant ships, war construction units (barracks, depots, airfields, etc., government-financed war plants and war housing); and a host of similar items. The group is dominated by items of specific use in the armed conflict and subject to the rapid qualitative changes associated with active warfare. The price indexes for it, based on compensation of resources rather than on prices of final 


\section{-}

products, were built up from separate measures for the resource categories: labor costs and gross profits, the latter in turn allocable between returns to capital and enterprise on the one hand, and cor. porate income and excess profit taxes on the other. The weights assigned to these three categories of resource cost indexes (the price adjustment was made separately for the three subtotals, each representing the relevant cost category) were based on the breakdown of gross value of output in the five 'war' industries (metal and oil and gas in mining, metals fabrication, chemicals and petroleum refining in manufacturing, and contract construction) that accounted for the bulk of munitions production and war construction in 1942 .

The price index for the labor factor is an index of hourly earnings in 44 war manufacturing industries weighted by current year man hours. The current cost of the capital and enterprise factor was derived by applying to the total value of munitions and war construction the changing ratio of the combined total of corporate net income after taxes, depreciation, entrepreneurial income, interest, and net rents and royalties to the gross value product of the five 'war' industries listed above. The corresponding price measure was obtained by dividing an index $(1939=100)$ of the total value of these items in the five 'war' industries by a measure of changes in the physical volume of capital and enterprise input, represented by an index of the consumption of raw materials of mineral origin prepared by G. H. Moore. Finally, it was assumed that the corporate taxes (income and excess profit) paid in 1939 were the monetary equivalent of the government's contribution to business activity; and that, after 1939, such services increased with real output, i.e., with deflated labor, capital, and enterprise costs. Accordingly, the ratio of 1939 taxes in the five 'war' industries to the 1939 total of labor, capital, and enterprise costs was applied to the deflated totals of such costs calculated for munitions and war construction. On the assumption used, the result measured government services at 1939 prices rendered in connection with these activities.

Clearly the assumptions adopted to derive price indexes for the various categories of resources embodied in munitions and war construction are open to challenge. Attempts to attach quantities to processes whose substantive scope is exceedingly difficult to ascertain, they are submitted here in the realization that fuller data may make better estimates possible in the future. But crude as the indexes are as measures of changes in compensation per resource unit entering 
munitions and war construction, the implicit assumptions are, on the whole, in the direction of under- rather than overestimating the rise in resource prices. In the case of both labor and the human part of capital and enterprise the procedure assumes that the groups involved are comparable through the years with respect to skill and training. But this means that the price indexes neglect the dilution of skill and experience in the labor and managerial groups. ${ }^{7}$ Furthermore, for both labor and nonlabor factors, the procedure assumes that, within the industries covered, compensation of factors engaged in war production increased from 1939 onward at the same rate as compensation of factors engaged in the same industry in peace-type work. That is, the indexes neglect the possibly greater increase by 1941 or 1942 in the pay to factors engaged in war production proper than in the compensation of factors still engaged in the same industries in peacetype work.

True, there are offsetting factors that might reduce the downward bias of the price indexes. The index of earnings per man hour covers wage earners in selected industries that by 1942 might be characterized as largely war industries. It is quite possible that price per unit of input of other labor entering war outlay (salaries in war industries, payments to employees in transportation or other areas serving war but not comprised in our index) may have risen less from 1939 to 1942 than the man hour earnings in the 44 manufacturing industries. Similarly, compensation to nonlabor factors, entering war outlay but not covered in our indexes, may have risen less than is indicated. However, a rough balancing of these considerations, which can be nothing except a guess, would suggest that the offsets indicated above would not serve to cancel fully the downward bias of the price indexes. Thus, like the price measures for other components of national product, and perhaps even to a greater degree, the indexes of compensation of productive factors entering war outlay tend to underestimate the effective price rise between 1939 and 1943.

Two aspects of the results of the procedures just described stand out. The first is the greater rise of prices in 1942 and 1943 shown by the index, Table 2, line 1, than by the customary cost of living index (line 5). For reasons indicated in the Appendix, Section 1c, part of the difference may be an improperly full imputation of our adjustments in food and clothing to the price indexes. Perhaps part of the

7 This may be compensated, but only in part, by the undervaluation of the services of the armed forces and war agency personnel included under nonmunitions. 
difference should be imputed to a bias in the current dollar value totals. On the other hand, as already indicated, the adjustments, and hence the index in line 1 , do not take full account of various hidden forms of price increase in many civilian goods. In our opinion, the difference between lines 1 and 5 for 1942 and 1943 should be rated an understatement.

TABLE 2

Price Indexes of Final Products and Resources Major Components of National Product, 1939-1943 $1939=100$

$\begin{array}{llllll}\quad \text { Prize Indexes for } & & & & & 1943 \\ & 1939 & 1940 & 1941 & 1942 & \begin{array}{c}\text { Hali } \\ \text { 1st }\end{array} \\ \text { 1 Flow of goods to consumers (excl. gov. services) } & 100 & 101 & 107 & 122 & 131 \\ \text { 2 Nonwar construction \& equipment, gross } & 100 & 101 & 107 & 112 & 116 \\ \text { 3 War outlay, gross } & 100 & 112 & 128 & 145 & 156 \\ 4 \text { Wholesale prices, BIS } & 100 & 102 & 113 & 128 & 134 \\ 5 \text { Cost of living, BLS } & 100 & 101 & 106 & 117 & 124\end{array}$

The indexes in lines 1-3 are implicit: they were derived by dividing the current dollar value totals by the corresponding totals in 1939 prices. For a detailed description of the procedures and the quarterly and annual totals see the Appendix, Section 1-4.

The second significant showing is the relatively sharp rise in prices of resources put into war outlay (line 3 ). Since the index covers also prices (at the final product level) for nonmunitions, which have risen less sharply, the rate of compensation of resources (associated with munitions and war construction proper) rose even more than is indicated in line 3.

Table 2 brings us to an intermediate stage in the analysis. The indexes in lines 1 and 2 (and some part of that in line 3) are for prices of final products; those dominating the entries in line 3 , for prices of resources. Were we to apply these indexes in the price adjustment of the relevant components of national product, one part of the total would represent a sum of final products at their 1939 prices; the other a sum of productive resources at their 1939 prices. The two parts (which were in fact added in Appendix Table 7) can be legitimately added only by one or two further steps: (1) estimate changes in the efficiency of resources in the area outside munitions and war construction, then convert the final product price indexes into measures of changes in the compensation of resources at their 1939 efficiency level; in which case the national product totals, when adjusted for price changes, become consistently measures of the 'real' volume of resource-input at constant efficiency level; or (2) estimate changes after 1939 in the efficiency of resources that were put into munitions 
and war construction, changes measured against the relative ${ }^{8}$ effciency of comparable resources (i.e., in the five 'war' industries) in 1939; then convert the totals for munitions and war construction into measures of final output, comparable with the other components of national product.

\section{$b$ Conversion to Prices of Resources}

Whatever scattered data on the efficiency of resources in the nonwar sector are available (chiefly in a few manufacturing and mining industries and utilities on a per man hour base) suggest that the rise since 1939 has been moderate, at an annual rate of not more than 2 or 3 per cent; that it virtually ceased by 1942; and that in recent quarters, as the scale of operations in many civilian industries declined and dilution of labor and other resources took place, efficiency per resource unit may have declined slightly.

On the basis of such meager evidence, a quarterly efficiency index was constructed and applied uniformly to the price indexes (at final product prices) for three of the major components of national product (flow to consumers, excluding direct taxes; nonwar construction and equipment; the nonmunitions part of war outlay). The price indexes for final products were thereby converted into price indexes for resources at their 1939 efficiency. ${ }^{\circ}$

Even if this single efficiency index is accurate, the application of one and the same index to such different groups of final products as are represented by consumers' outlay, nonwar construction and equipment, and nonmunitions is clearly arbitrary. Efficiency of resources put into construction and equipment may have risen less or more than efficiency of resources in the production, transportation, and distribution of consumer goods; and it may well be asked how productivity of resources in such a heterogeneous category as 'nonmunitions' can be gauged. But it seemed preferable to make the assumption, on whatever little ground could be found, then show the modification in the customary measures called for, if only to stress the questions that must be answered in any consistent estimate of national output or input in real terms.

Comparison of the indexes in Tables 2 and 3 reveal relatively minor differences, largely because the scanty data indicate merely

8 Relative to efficiency of resources in the rest of the economy.

${ }^{9}$ See Appendix, Section 5, especially Appendix Tables 8 and 9. In actual calculations adjustments were made in the totals 'deflated by final product prices. 
minor changes in the efficiency of resources embodied in the flow of goods to consumers and other components aside from munitions and war construction.

TABLe 3

Price Indexes of Resources

National Product and Its Components, 1939-1943

$1939=100$

$\begin{array}{llllll}\quad \begin{array}{c}\text { Indexes of Prices } \\ \text { of Resowres Embodied in }\end{array} & 1959 & 1940 & 1941 & 1942 & \begin{array}{c}1943 \\ \text { Half }\end{array} \\ 1 \text { Flow of goods to consumers (excl. gov. services) } & 100 & 103 & 112 & 129 & 138 \\ 2 \text { Nonwar construction \& equipment, gross } & 100 & 104 & 112 & 118 & 122 \\ 3 \text { War outlay, gross } & 100 & 112 & 130 & 147 & 158 \\ 4 \text { Gross national product } & 100 & 104 & 113 & 133 & 145 \\ 5 \text { Net national product } & 100 & 104 & 114 & 135 & 148\end{array}$

All indexes are implicit, and were derived by dividing the current dollar value totals by the corresponding totals in 1939 resource prices.

Since changes in the prices of all components are measured on the same base in Table 3, price indexes implicit in the national product totals can be derived. ${ }^{10}$ It must be clearly understood that these are indexes of resource prices, and that, strictly speaking, the totals to which they apply are not those of national product, i.e., final output, but of national resource-input."

The striking features of these indexes (lines 4 and 5) are their rise to relatively high levels by 1943 and the acceleration of the rise after 1941. In the two years 1939-41 they rose only 13-14 per cent; in the following year and three-quarters almost 30 per cent, partly because of a fairly steep rise from 1941 to the first half of 1943 in resource prices in war outlay, partly because of the large increase in the weight of war outlay in national product.

\section{c Conversion to Prices of Final Products}

The main question here concerns the relative efficiency of resources used in munitions production and war construction. The only evidence is scattered information on the change in labor efficiency in some areas of munitions production (planes, merchant ships), which suggests a marked rise in labor productivity in munitions industries. There are no data that would serve even to suggest the relative effici-

10 This is true with the exception of government services to individuals (direct taxes). which are included at the same absolute level in the current dollar and price adjusted indexes.

II Not the full total of all resourceinpus activitics (e.g., robbery or fesource-input since resources devoted to clearly unproductive embraces only resource-input in uses nog peddling) are presumably excluded. The total 
ency of resources in munitions and war construction compared with their productivity in similar (i.e., five 'war') industries in 1939except again fragmentary data on loss of labor time paid for due to labor 'hoarding', difficulties of attaining a smooth flow of materials and components, and troubles arisilg from rapid changes in technical specifications due to fluid conditions of active warfare.

For lack of evidence, assumptions had to be made. The results, of illustrative value, can be converted into tentative substantive conclusions only by an exercise of judgment. The three assumptions in the calculation differed in the relative efficiency assigned to resourceinput for the first half of 1943. Assumption a set the level of efficiency in munitions and war construction at 80 ; for the other areas in total output, at 105 . This meant that whatever the efficiency ratio of resources in the five 'war' industries to resources in all 'other' industries was in 1939, the corresponding ratio in the first half of 1943 was lower by the proportion of $(105-80) / 105$. Assumption $b$ set the relative efficiency level in munitions and war construction in the first half of 1943 at the efficiency ratio of the five 'war' industries in 1939. Assumption $c$ set the relative efficiency level in munitions and war construction in the first half of 1943 higher than the corresponding ratio for the five 'war' industries in 1939 , by the proportion of $(130-105) / 105 .{ }^{12}$

The three assumptions specify different levels of relative efficiency of munitions production and war construction in the first half of 1943 compared with other industries. In addition, we assume for all three a similar movement of the relative efficiency level between 1939 and the recent quarters, namely: (i) that relative efficiency increased twothirds from 1939 to the first half of 1943; (ii) that the increase was fairly steady through 1941; (iii) that in the last quarter of 1941, but especially in the first and second quarters of 1942, the upward trend was damped by the precipitous expansion of munitions production and war construction; (iv) that relative efficiency rose rapidly after

12 The assumptions indicate nothing concerning the efficiency of resources in munitions and war construction on the one hand, and in all other production, on the other. They relate directly to the ratio between two ratios: (i) the ratio in 1939 between efficiency in five "war" industries and in other sectors of national output; (ii) the ratio between efficiency in munitions and war construction in 1943 and efficiency in other sectors of national output. Assumption states that the ratio of (ii) to (i) is 0.76 (i.e., $(80 / 105): 1$ ); assumption $b$ that it is 1.0 (i.e., $(105 / 105): 1$ ); assumption $c$ that it is 1.24 (i.e., $(130 / 105): 1)$. However, the assumptions imply a relation between the efficiency of resources in munitions production and war construction in 1943 and in five "war" industries in 1939: by assumption $a$, the former is at a level of 0.8 of the latter; assumption $b$. of 1.05 , by assumption $c$, of 1.3 . 
the second quarter of 1942 as plants were completed, mass production of munitions began to hit its stride, and the pains of rapid growth subsided. ${ }^{13}$

Upon these assumptions, we convert indexes of resource prices for munitions production and war construction into indexes of final output prices, with prices on the same bases as comparable products were valued in a prewar year like 1939 (Table 4, lines 3a, 3b, and 3c). Since these indexes are consistent with those for the flow of goods to consumers and nonwar capital formation, implicit measures of price changes in total national product also can be derived (Table 4, lines 4 and 5).

Clearly, the price indexes for war outlay are not in terms of 1939 as 100: they could yield such an entry comparable with one of 100 for prices in other sectors of final output only if the efficiency of resource-use in war production could be assumed to stand in the same relation to efficiency in these other sectors of output as characterized the five comparable industries at their 1939 productivity level. The degree to which the entries in lines $3 a, 3 b$, and $3 c$ exceed 100 in 1939 is a measure of how far the relative efficiency of resources in war production was assumed to fall short of that in comparable industries in 1939.

If we wish to measure temporal price changes alone, without correcting for any differences in the way prices measure real output in the war sector as compared with the nonwar, entries in Table 4 , lines $3 a, 3 b$, and $3 c$, can be converted to relatives of 1939 and the results averaged. The price index so derived, line 6 , rises moderately to 1942 , then declines to the first half of $1943 .{ }^{14}$

Differences among the various price indexes in Table 4 are as might be expected. If we allow for the lower efficiency of resource-use in war production as compared with the rest of the economy, and thus for a higher price level in it, the very increase in the proportion of war outlay in national product causes an upward movement in the price indexes for national product as a whole. Thus, under assump-

13 The assumed movement in the relative efficiency of resource use, as distinct from the level assumed for the first half of 1943, is based for the years since 1941 upon a rough check with the expansion in munitions output weighted by constant prices. The three assumptions concerning the relative efficiency level in the first half of 1943 are illus-
trative; and the preference, in subsequent discussion, for assumption a is based largely
upon scattered evidence of lavish (by peacetime standas) upon scattered evidence of lavish (by peacetime standards) use of manpower and mate-
rials in war production.

11 For detailed calculations see Appendix Table 13. 
tion $a$ the over-all price index rises 50 per cent from 1939 to the first half of 1943 (lines $4 a$ and 5a). The failure to allow for the lower efficiency of resources in war outlay yields an over-all price index that rises only 18 or 19 per cent from 1939 to 1942 , and in 1943 rises somewhat less than 1 per cent further (lines 7 and 8 ).

\section{TABLE 4}

Price Indexes of Final Products

Three Assumptions concerning the Relative Efficiency of Resource-Input in Munitions Production and War Construction, 1939-1943

\section{Price Indexes for}

1939

1 Flow of goods to consumers (excl. gov. services) 100

2 Nonwar construction \& equipment, gross 100

3 War outlay, gross
a) Assumption a
b) Assumption $b$
c) Assumption c

4 National income
a) Assumption a
b) Assumption $b$
c) Assumption $c$

$\begin{array}{lllll}1939 & 1940 & 1941 & 1942 & \begin{array}{c}1943 \\ \text { Ist } \\ \text { Half }\end{array} \\ 100 & 101 & 107 & 122 & 131 \\ 100 & 101 & 107 & 112 & 116 \\ 163 & 175 & 188 & 190 & 182 \\ 138 & 148 & 157 & 158 & 150 \\ 119 & 126 & 134 & 133 & 127 \\ 101 & 102 & 113 & 140 & 154 \\ 101 & 102 & 111 & 133 & 141 \\ 100 & 102 & 109 & 126 & 130 \\ 101 & 102 & 112 & 138 & 150 \\ 101 & 102 & 110 & 131 & 138 \\ 100 & 101 & 109 & 124 & 128 \\ & & & & \\ 100 & 107 & 114 & 114 & 109 \\ 100 & 101 & 108 & 119 & 120 \\ 100 & 101 & 107 & 118 & 119 \\ 100 & 101 & 106 & 114 & 117\end{array}$

5 Gross national product
a) Assumption a
b) Assumption b
c) Assumption c

6 War outlay, disregarding relative efficiency in war production

7 National income (based on lines 1, 2, 6)

8 Gross national product (based on lines 1, 2, 6)

9 Gross national product, Dept. of Commerce adjustment \& concept

Lines 1 and 2 from Table 2. For detailed calculations of entries in lines 3a, 3b, 3c, see Appendix, Section 6. Entries in lines 4 and 5 derived from current dollar value and price adjusted totals (see App. Tables 6 and 12).

Line 6: arithmetic mean of relatives of lines $3 a, 3 b$, and $3 c(1939=100)$.

Lines 7 and 8 calculated from current dollar value totals (App. Table 6) and price adjusted totals (adjusted by lines 1, 2, and 6). Line 9 derived by dividing Department of Commerce gross national product totals by its totals reduced to 1939 prices. The concept in line 9 is one that includes in gross national product all government outlays (see note 2 ).

It is significant that the index implicit in the Department of Commerce adjustment of gross national product for price changes is similar to that in line 8 . In its adjustment the Department assumes that final prices of munitions do not change over time, and that they are comparable with prices in the nonwar sectors of the economy. This is tantamount to saying that a war outlay price index is affected only by changes in the prices of nonmunitions (and in the Department's calculations also by changes in construction costs used to 'de- 
flate' war construction). The resulting price index is bound to be similar to an index measuring only temporal changes in the prices of war outlay, without allowing for the relatively lower efficiency of resource-use. Line 9 differs from line 8 only in that it is somewhat lower in 1942 and 1943, and rises slightly more from 1942 to 1943. Both differences are due to the specific assumptions used here as to the movement over time in the efficiency of resource-use in munitions and war construction.

\section{NATIONAL PRODUCT AT CONSTANT PRICES}

\section{a The Several Variants}

With the alternative price indexes discussed in Section 4, national product totals and their components at constant price levels in several variants are derived (Table 5). The meaning of each variant must be clearly perceived before the differences they show in the movement of national product over time, in the distribution among the major components, and in the relative magnitudes of the absolute increases and declines in the components and the totals can be analyzed.

The variants in lines 1 represent an adjustment of current dollar figures by indexes that measure changes in prices of resources (base 1939). The results of such an adjustment are, therefore, sums of resources valued at their 1939 prices. Line 1-1, e.g., is the sum of productive resources embodied in the flow of goods to consumers, these resources weighted at their 1939 prices, i.e., at their 1939 efficiency as represented by the prices they fetched in that year. $A$ similar statement, with modifications in the description of the categories of final products into which the resources entered, can be made for lines Il-1, III-1, IV-1, and V-1.

The variants in lines 2 represent an adjustment of current dollar figures by indexes that measure changes in final product prices. The four variants differ in the degree to which they allow, in the transition from the resource level of measurement to the final product level of measuring munitions and war construction, for differences in the relative efficiency of resource-use. The variants under (a), (b), and (c) assume that the resource-use in munitions and war construction is at an efficiency level (relative to the rest of the economy) different from that characterizing similar types of industrial output (i.e., largely of the metal working, chemical, and construction industries) in 1939. The variant under (d) disregards such differences in effi- 
ciency level between munitions and war construction and its prewar civilian counterpart, and adjusts the current dollar value figures only for temporal changes in the final product prices of war goods.

\section{TABLE $S$}

National Product and Its Components, Wartime Concept, 1939-1943 1939 Prices, Final Product and Resource Levels (dollar figures in billions)

Componens's and Toials

J Flow of goods to consumers

1 At resource prices

2 At final product prices

II Nonwar capital formation, gross

1 At resource prices

2 At final product prices

III War outlay, gross

1 At resource prices

2 At final product prices
a) Assumption a
b) Assumption $b$
c) Assumption c
d) Disregarding relative efficiency in war production

IV Net national product

1 At resource prices

2 At final product prices
a) Using III-2a, net
b) Using III-2b, net
c) Using III-2c, net
d) Using III-2d, net

V Gross national product

1 At resource prices

2 At final product prices
a) Using III-2a
b) Using III-2b
c) Using III-2C
d) Using III-2d

\begin{tabular}{|c|c|c|c|c|}
\hline 1939 & 1940 & 1941 & 1942 & $\begin{array}{c}\text { Ist } \\
\text { Halt }\end{array}$ \\
\hline 64.8 & 66.6 & 69.9 & 66.9 & 68.1 \\
\hline 64.8 & 68.2 & 73.1 & 70.2 & 71.3 \\
\hline 13.2 & 16.0 & 18.8 & 7.9 & 0.2 \\
\hline 13.2 & 16.4 & 19.5 & 8.3 & 0.4 \\
\hline 1.4 & 2.4 & 9.6 & 33.5 & 51.3 \\
\hline 0.8 & 1.6 & 6.6 & 26.0 & 44.4 \\
\hline 1.0 & 1.8 & 7.9 & 31.2 & 54.0 \\
\hline 1.1 & 2.2 & 9.4 & 37.0 & 63.8 \\
\hline 1.4 & 2.5 & 10.9 & 43.3 & 74.4 \\
\hline 72.2 & 77.6 & 90.4 & 99.0 & 109.5 \\
\hline 71.6 & 78.8 & 91.3 & 95.2 & 105.9 \\
\hline 71.8 & 79.0 & 92.6 & 100.4 & 115.5 \\
\hline 71.9 & 79.4 & 94.1 & 106.2 & 125.3 \\
\hline 72.2 & 79.7 & 95.6 & 112.4 & 135.9 \\
\hline 79.4 & 85.0 & 98.3 & 108.3 & 119.6 \\
\hline 78.8 & 86.2 & 99.3 & 104.5 & 116.1 \\
\hline 79.0 & 86.4 & 100.6 & 109.7 & 125.7 \\
\hline 79.1 & 86.8 & 102.0 & 115.5 & 135.5 \\
\hline 79.4 & 87.1 & 103.6 & 121.7 & 146.1 \\
\hline
\end{tabular}

All entries except III-2d, IV-2d, and V-2d from Appendix Tables 7, 9, 10, 11, and 12. The $d$ line entries are calculated with the help of the index in Table 4 , line 6 .

Lines $2 \mathrm{a}$ are then the sums of final products weighted by their 1939 prices, on the assumption that in converting resource-input in munitions and war construction into final products, the efficiency of use, relative to the rest of the economy, was in 1939 at .48 of the relative efficiency level of comparable peacetime industries (metal mining and manufacturing, chemicals and construction) and rose to 0.8 by the first half of 1943. The same statement could be repeated for entries in lines $2 b$ and $2 c$, with changes in the ratios to 0.63 and 1.05 ; and 0.78 and 1.3 respectively. ${ }^{15}$

15 This statement repeats the assumptions as to both relative levels and movement discussed in Section $4 c$. 
Lines $2 \mathrm{~d}$ are quite different: they are the sums of final products weighted by their 1939 prices; but without any allowance, in converting resource-input in munitions and war construction into final products, for any difference in the relative efficiency of use (relative to the rest of the economy) from that in comparable peacetime industries.

The distinction between the estimates at resource and at final product levels is clear; and which is chosen depends primarily on the specific use to which the estimates are to be put. Similarly, the choice between the final product totals that do $(a, b, c)$ and do not (d) allow for differences in relative efficiency between war production and peacetime production of comparable character is also clear: for any purposes in which national product totals, in real terms, are to be compared as between prewar and war years and in which relative magnitudes of war and other production are to be established in final product terms, only variants of the (a) to (c) type should be employed.

But the choice among the three variants expressing different assumptions concerning the relative efficiency of resources in munitions and war production is not easy; for it is based, not on theoretical criteria, but on differences in the validity of assumptions concerning a phenomenon, accurate observation of which is extremely difficult. As already indicated, preference for any of these three variants (or any of this type using different levels of and trends in the relative efficiency of war production) cannot be grounded upon much tangible evidence and is a matter of rough judgment.

In making this judgment it should be noted that as far as the national product totals and their distribution are concerned, the choice among the variants $a, b$, and $c$ (and perhaps any others of similar character that may reasonably be devised) is of quantitative importance only for 1942 and 1943 . Before 1942 total war outlay was too small a proportion of national product (no matter how measured) for differences in its price adjustment to have much effect. Even in 1942 the spread among the three variants (for the national product totals) is about 10 per cent. Only in the first half of 1943 do the quantitative effects of the choice among the three variants become decisive.

We definitely prefer variant $a$, with its assumption that the relative efficiency of resource-use in war production in the first half of 
1943 was still below that of comparable prewar industries. This judgment should be clearly understood as referring to efficiency in munitions and war construction in 1943, not as compared with it in the same industries in 1942,1941 , or 1939 , or as compared with that of resources in nonwar industries in 1943 or any earlier year. The judgment is that, relative to the efficiency of resource-use in comparable prewar industries in 1939, that of resources in munitions and war construction in the first half of 1943 was still lower, some 20 per cent. In other words, utilization of labor (measured, e.g., by idle hours out of total paid or by diversion to lesser jobs to fill in gaps); of materials (measured, e.g., by rates of consumption compared with those at more mature stages of technology); of machinery (measured not at time rates but at input rates per unit, compared again with the practices of the more mature and gradually developing industries such as those of peacetime) was, in the first half of 1943 , still below the prewar par.

Our preference should not be interpreted as an adverse verdict upon this country's enterprise or as depreciation of the enormous task met during the months since our entry into the war. That with the pressure to turn out munitions in huge quantities, with rapidly changing demands of warfare, and with drains upon manpower and management by calls into the armed forces, relative efficiency in war production can be assumed to be only 20 per cent below that of comparable peacetime industries is a matter for congratulation rather than condemnation. But just as it would be dangerous to minimize the gigantic productive task met, so would it be misleading to ignore the patent fact that resources were not used as economically as they night have been had the more efficient methods feasible with slower growth under more normal competitive conditions been possible. Regardless of the validity that may be attached to the specific figure used in assumption a (which should perhaps be somewhat higher or lower), we believe that an assumption that assigns to war produciion a lower level of relative efficiency in the first half of 1943 than existed in similar industries before the war is decidedly more plausible than assumptions that put it equal to or above the standard set by comparable industries before the war.

\section{b Increase over the Period}

As already indicated, the estimates that seem preferable are either those that value the national product at resource prices or at final 
product prices on assumption $a$; and discussion is confined to those two.

The totals, whether gross or net, are roughly 50 per cent greater in the first half of 1943 than in 1939 (Table 6). Of this increase, about one-half occurred before this country entered the war. The increase in national product during the year and three-quarters asso. ciated with active participation in the war is not significantly greater than that during the preceding two years.

These findings differ considerably from those suggested by the Department of Commerce totals, and by such widely used measures of industrial production as the Federal Reserve Board index. The De-

\section{TABLE 6}

Percentage Increase in National Product, Wartime Concept, Selected Periods 1939 Prices, Several Variants

I Net national product

1 At resource prices

2 At final product prices

i) Regarding relative efficiency in war production in assumption $a^{1}$

ii) Disregarding relative efficiency in war production

II Gross national product

1 At resource prices

2 At final product prices

i) Regarding relative efficiency in war production in assumption $a^{1}$

ii) Disregarding relative efficiency in war production

III Other measures

1 Dept. of Commerce G.N.P. in 1939 prices

i) Dept. of Commerce concept

ii) Adj. to our concept

2 FRB industrial production index

1 Net national product

Assumption $b$

Assumption c

Gross national product

Assumption $b$

Assumption c

$\begin{array}{cccccc}1941 & 1942 & 1942 & 1943 & 1943 & 1943 \\ \text { over } & \text { over } & \text { crer } & \text { over } & \text { over } & \text { over } \\ 1939 & 1941 & 1939 & 1942 & 1941 & 1939 \\ (1) & (2) & (3) & (4) & (5) & (6) \\ & & & & & \\ 25.2 & 9.5 & 37.1 & 10.5 & 21.0 & 51.5\end{array}$

$\begin{array}{llllll}27.5 & 4.3 & 33.0 & 11.2 & 16.0 & 47.9\end{array}$

$\begin{array}{llllll}32.4 & 17.6 & 55.7 & 20.9 & 42.2 & 88.2\end{array}$

$\begin{array}{llllll}23.8 & 10.2 & 36.4 & 10.4 & 21.7 & 50.6\end{array}$

$\begin{array}{llllll}26.0 & 5.2 & 32.6 & 11.1 & 16.9 & 47.3\end{array}$

$\begin{array}{llllll}30.5 & 17.6 & 53.4 & 20.0 & 41.0 & 84.0\end{array}$

$\begin{array}{rrrrrr}26.7 & 18.2 & 49.8 & 16.5 & 37.7 & 74.5 \\ 31.5 & 20.1 & 58.0 & 17.5 & 44.1 & 85.7 \\ 48.6 & 22.8 & 82.5 & 17.1 & 43.8 & 113.8 \\ & & & & & \\ 29.0 & 8.4 & 39.8 & 15.0 & 24.7 & 60.9 \\ 30.9 & 12.9 & 47.7 & 18.0 & 33.2 & 74.3 \\ & & & & & \\ 27.3 & 9.0 & 38.9 & 14.6 & 25.0 & 59.1 \\ 29.0 & 13.2 & 46.0 & 17.3 & 32.8 & 71.3\end{array}$

Entries under I and II based on Table S. Entries under III based on Department of Commerce figures and the Federal Reserve Board index (revised as of Oct. 1943).

1943 values used in these calculations are annual rates covering the first half of the calendar year. 
partment of Commerce total of gross national product, based upon its concept and price adjustment, rises 75 per cent; only one-third of this increase occurs between 1939 and 1941. Readjusted to our concept, its total rises 86 per cent from 1939 to the first half of 1943: only somewhat more than one-third of this increase occurs during the first two years. The Federal Reserve Board index, which would naturally rise more since it is more heavily weighted by industrial commodity production, rises 114 per cent from 1939 to the first half of 1943; four-tenths of the increase occurs between 1939 and 1941. The difference between the estimates devised and preferred here and those used by the Department of Commerce is due largely to a different treatment of the value of war production; that between our measures and the Federal Reserve Board index is due partly to a difference in coverage and partly to a different treatment of productivity of factors in the war industries. ${ }^{16}$

The rates of increase in our national product total at resource or at final product prices are in themselves not unusual. In the two decades, 1919-38, for which annual estimates are available there are increases of the same relative magnitude. From 1921 to 1923 national income in 1929 prices rose 25 per cent and gross national product 23 per cent; from 1935 to 1937, they rose 23 and 21 per cent respectively. These increases compare with a 24 to 27 per cent increase from 1939 to 1941; and with an increase of either 16 or 22 per cent from 1941 to the first half of 1943 . Selecting a longer period, we find that from 1933 to 1937 , four years, national income in constant prices increased 43 per cent and gross national product 37 per cent, which compares with roughly 50 per cent from 1939 to the first half of 1943. From 1933 to 1936 the increase in national income in constant prices was 32 per cent and in gross national product 28 per cent, compared with 37 and 33 per cent increases from 1939 to $1942 .{ }^{17}$

These numerical comparisons, however, disregard the phase of the business cycle represented by the initial years. Each period selected

16 The FRB index is based, for recent years, upon man hour input in many war industries, weighted by productivity levels extrapolated from 1939. No allowance is made for possibly lower efficiency levels in the war industries as compared with relative efficiency of similar industries in 1939.

17 All figures for national income 1919-38 from National Income and Its Composition, National Bureau, 1941, I, Table 5, p. 147, and for gross national product from unpublished estimates prepared by the National Bureau of Economic Research. The comparison should properly be confined to the variant at final product prices, since national income figures have been adjusted for price changes with the help of final product price indexes. But during relatively short periods in the more 'normal' peace years, the difference in movement between the two levels would not be sizable. 
from the two decades 1919-38 begins with a year of deep depression, either 1921 or 1933, with the sole exception of 1935-37, and even 1935 was a year fairly low in the cyclical expansion phase. Under such conditions total output in real terms may easily rise by substantial percentages within a fairly short period. In contrast, 1939 was not a year of depression: the level of activity (as measured by national income or gross national product in constant prices) somewhat exceeds that of the preceding peak year in the business cycle, 1937. To attain large relative rises, as much as 50 per cent during somewhat less than four years, from such a relatively high base is an achievement unique in the historical course of our national economy during recent decades. $^{18}$

\section{c Share of War Outlay}

The changing ratio of war outlay to national product is of particular interest in wartime as an indication of the proportion of resources or final products devoted to war. As a measure of the full impact of the war upon the national economy, it has serious limitations: it disregards the effect of the war on the capital structure of the country, while its meaning in terms of effects upon the welfare of the population is obviously contingent upon the level of national product per capita, the rate at which civilian supply per capita declines, and the

\section{(Note 17 concl.)}

It may be argued that the comparison is improper, since in any cyclical expansion the portion of total output accounted for by the less efficient 'new' industries (similar to munitions and war construction) may increase; and a procedure similar to the one used here to get at a comparable valuation of final products would tend to accelerate the upward rate of the price indexes and thus retard the rise in the price-adjusted totals. No such price adjustment was applied to the estimates for 1919-38.

The validity of this argument depends upon the correctness of the assumption that there is a substantial rise during cyclical expansions in the proportion of output by the less efficient 'new' industries (beyond the rising secular trend in their share). It is to be doubted greatly that such an increase even approrimates the degree to which the relative share of war outlay increased in 1942 and 1943, at least for areas in peacetime economy so 'new' and so far below comparable industries in general in relative efficiency as were munitions and war construction.

18 Somewhat more significant results might have been obtained in this analysis had we attempted to measure the rise in national product in relation to the underlying long term trend, instead of from a given point of time. However, the establishment of such a trend is beset with difficulties; and its values at the end of the long period to which the trend line would have to be fitted would be subject to particularly wide margins of error.

Another refinement of the estimates in Table 6 (and in Tables 7 and 8 ) is to base them on quarterly rather than annual totals. These quarterly estimates, presented in the Appendix, can be used in calculations that span the full period and distinguish betwcen the quarters prior to and following Pearl Harbor. In view of the approximate character of the estimates and the greater margin of error in the quarterly than in the annual totals, it did not seem necessary to go beyond the annual totals. 
distribution of goods among consumers. However, it is a rough approximation to what is wanted; and in view of its wide current usage, its movement should be established on the basis of estimates derived here.

The share of war outlay in national product increased rapidly from 1939 to the first half of 1943 - from 1 or 2 per cent to a percentage running from 38 to 45 ; also, as would be expected, most sharply from 1941 to 1942 (Table 7).

\section{TABLE 7}

Percentage of War Outlay in National Product, Wartime Concept, 1939-1943 1939 Prices, Several Variants

I Net national product

1 At resource prices

2 At final product prices

\begin{tabular}{|c|c|c|c|}
\hline 1939 & 1940 & 1941 & 1942 \\
\hline 1.9 & 3.1 & 10.3 & 32.7 \\
\hline
\end{tabular}

i) Regarding relative efficiency in war production in assumption $a^{1}$

ii) Disregarding relative efficiency in war production

11 Gross national product

1 At resource prices

2 At tinal product prices

i) Regarding relative efficiency in war production in assumption $a^{1}$

ii) Disregarding relative efficiency in war production

$\begin{array}{rrrrr}1.1 & 2.0 & 6.9 & 26.2 & 40.2 \\ 1.9 & 3.1 & 11.1 & 37.5 & 53.3 \\ 1.8 & 2.8 & 9.8 & 30.9 & 42.9\end{array}$

III Other measures

1 Dept. of Commerce G.N.P. in 1939 prices

i) Dept. of Commerce concept

ii) $\mathrm{Adj}$. to our concept

$\begin{array}{rrrrr}1.0 & 1.9 & 6.6 & 24.9 & 38.2 \\ 1.8 & 2.9 & 10.5 & 35.6 & 50.9\end{array}$

1Net national product

Assumption b

Assumption c

Gross national product

Assumption $b$

Assumption $c$

$\begin{array}{lllll}1.6 & 2.8 & 10.5 & 33.3 & 46.3\end{array}$

$\begin{array}{lllll}1.8 & 3.1 & 11.3 & 35.3 & 48.5\end{array}$

See source notes to Table 6.

$\begin{array}{lllll}1.4 & 2.3 & 8.2 & 30.0 & 45.2\end{array}$

$\begin{array}{lllll}1.5 & 2.8 & 9.7 & 33.8 & 49.5\end{array}$

$\begin{array}{lllll}1.3 & 2.1 & 7.9 & 28.4 & 43.0\end{array}$

$\begin{array}{lllll}1.4 & 2.5 & 9.2 & 32.0 & 47.1\end{array}$

Differences between our estimates and those of the Department of Commerce are relatively minor. Even if we apply the Department's method of price adjustment to our concept, the share in 1942 and the first half of 1943 does not greatly exceed that measured here at resource prices, partly because our adjustment corrects the prices of both consumer goods and war outlay for upward biases. Consequently, the relevant distribution of national product, which in 1942 and 1943 is almost completely accounted for by these two components, is not greatly affected. 
However, there is a sizable difference between the share of war outlay for 1942 as measured here in final product prices (variant $a$ ) and the Department's. Indeed, the most significant finding in Table 7 is the difference between the shares at the resource price and final product price (variant $a$ ) levels. If one thinks of the distribution of resources regardless of their efficiency, war outlay in 1942 accounts for over onethird of the national total, whether gross or net. But adjusted for relative efficiency in the use of resources and expressed in terms of final products, it is only about one-fourth. This difference is natural since we assume that in the first year of active participation in the war a larger proportion of the country's resources was used, because of lower efficiency, to turn out a share of final products that was not correspondingly larger. The difference between the two ratios had narrowed materially by the first half of 1943; and if efficiency continues to improve the difference will vanish, or perhaps even change sign.

\section{d Source of Increase in War Oullay}

More commodities and services can be produced for the armed conflict either by shifting resources from civilian to war production or by increasing the total resources put into active use, or by both methods. When the increase in war outlay and the changes in the nonwar components of national product and total product itself are compared in terms of current prices (and appropriate categories), they indicate the financial sources of war outlay; but cannot properly be used to study the resource or final product balance. However, Table 8 includes not only the totals and components at constant resource or product prices, but also at current prices-primarily to indicate how misleading the current dollar totals can be in periods of rapid differential price shifts.

From 1939 to 1941 the several variants of national product and its components at constant prices are roughly similar (Table 8, Part A). There is a substantial increase in total national product and an increase in each of the three major components-war outlay, flow of goods to consumers, and other components (nonwar capital formation in our concept, private gross capital formation plus nonwar government outlay in the Department of Commerce total). The rise in war outlay is a fraction of the total rise in national product-in practically all variants less than a half, and ranging in general from onefourth to somewhat over one-third. Even the current price totals are fairly similar, largely because prices rose little. 


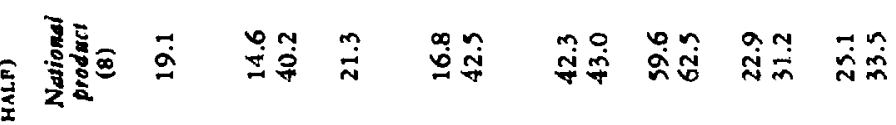

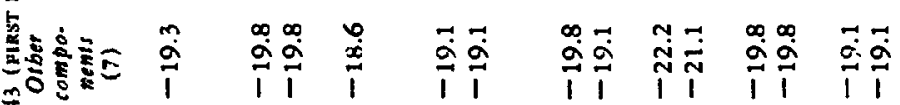
事

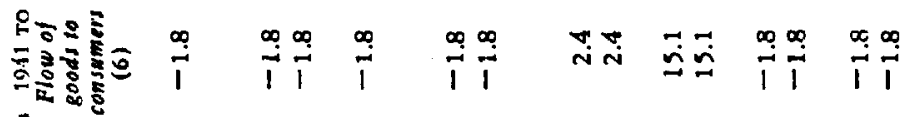

泀

in

D电

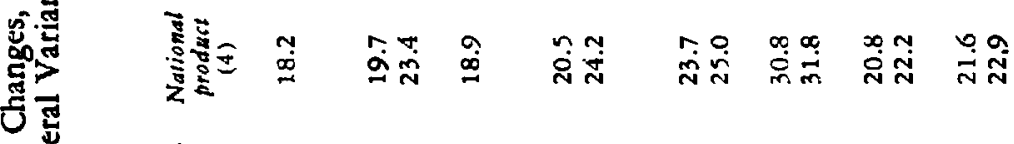

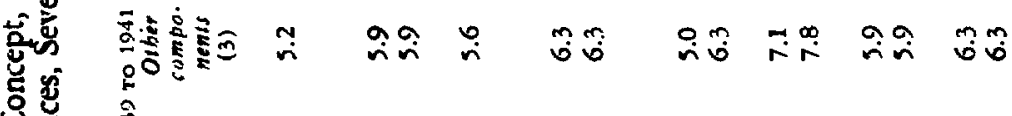

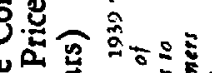

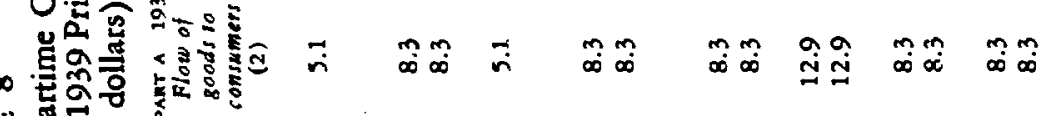
แै 最兽

द्ด

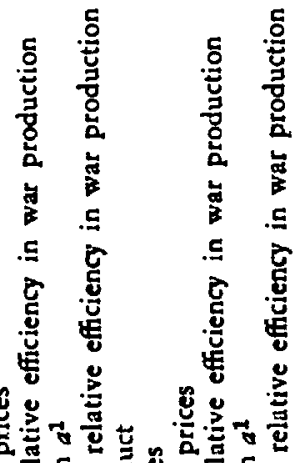

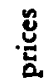

a

도월 
The picture from 1941 to the first half of 1943 is quite different (Table 8, Part B). In general, war outlay climbs precipitously, appreciably more in every variant than total national product. The difference between the two is balanced by a marked decline in the 'other' components, i.e., nonwar capital formation (and, in the Department of Commerce concept, nonwar expenditures of government, although the decline in it is minor).

The significant differences among the several variants for 1941-43 are in the extent to which the rise in war outlay can be associated with an increase in national product or accounted for by declines in the nonwar components. Measures based on our concept and in the variants that seem preferable, i.e., totals at resource or at final product prices (variant a), indicate that somewhat less than one-half of the increase in war outlay is accounted for by a rise in total national product. The other half is balanced by a decline in nonwar capital formation and a very minor drop in the flow of goods to consumers.

In the Department of Commerce estimates, either based upon its own concept or adjusted to our concept, the rise in national product amounts to 70 , instead of less than 50, per cent of the rise in war outlay from 1941 to the first half of 1943. The decline in the 'other' components, i.e., chiefly in private gross capital formation, amounts to less than one-third of the increase in war outlay; and the balance is accounted for by a minor rise in the flow of goods to consumers. ${ }^{19}$

An even more strikingly different picture is suggested by the current dollar totals if we assume that the rise in national product should be associated first and completely with the increase in war outlay. On this assumption almost 90 per cent of the increase in war outlay is accounted for by the increase in total national product, and only 10 per cent by the net reduction in the nonwar components combined. Obviously the impression that the tremendous increase in war pro. duction has been attained to such a preponderant extent by an increase in national output and to such a minor extent by drafts upon nontvar output - an impression that can all too easily be formed on the basis of current dollar figures-is far from the truth, if the analysis of the total product in real terms, as suggested in the upper part of Table 8 , is at all valid.

19 This calculation is based upon counting the full rise in national product as a source of the rise in war outlay, rather than allowing part of it to account for the rise in the flow of goods to consumers. The results would be practically the same were we to reduce the increase in national product by the increase in the flow of goods to consumers, and treat the remainder alone as a source of augmented war outlay. 


\section{SUMMARY}

a) National product in wartime is defined as the sum of finished output: (i) flow of goods to ultimate consumers; (ii) additions to the stock of nonwar capital; (iii) flow of goods to war uses; (iv) additions to the stock of war capital. ${ }^{20}$ It is net or gross as components (ii) and (iv) are taken net or gross of the current consumption of durable capital goods.

b) Changes in prices over time and differentials in pricing bases between the nonwar and war components are large during a major war. Consequently, estimates of national product and its components at current prices become misleading as indexes of movements in the totals and in the relative proportions of components in 'real' terms, i.e., as physical volumes weighted by prices constant over time and consistent as to base among the several components.

c) In passing from totals at current to totals at constant prices, the adjustment must be so designed as to take into account both changes in prices over time and the differences in pricing bases between war and nonwar production. Only in such a way can a continuous series of comparable measures, spanning both prewar and war years, be derived.

d) Such an adjustment is attempted here on two levels. First, indexes, based on 1939, of changes in the prices of resources from 1939 to 1943 were computed. Their application to current dollar value totals yielded estimates of resource-input, total and for the major components of final output, resources being weighted at 1939 prices and thus at their 1939 relative efficiency levels. Second, with the help of assumptions concerning the relative efficiency of resource-use in the production of munitions and in war construction, all indexes were converted into measures of changes in the prices of final products. Their application to current dollar value totals yielded estimates of final output, total and for the major components, weighted by their 1939 prices and with war goods priced on a base comparable with that of peace-type products.

e) Total national product adjusted for changes in the prices of resources (i.e., total input of resources at their 1939 efficiency and price levels) increased slightly more than 50 per cent from 1939 to the first half of 1943. In terms of final output and on the most plausible assumption concerning the relative efficiency of munitions pro20 Components (iii) and (iv) are referred to subsequently as war production or the wat sector; and components (i) and (ii) as nonwar. 
duction and war construction, total national product increased some. what less. Both increases are appreciably less than that shown by the Department of Commerce gross national product totals in 1939 prices. Estimates based on the Department's concept and price adjustments increase 75 per cent; those based on our concept but using the Department's price adjustments 86 per cent.

f) An increase in either gross or net national product, at constant prices, of about 50 per cent during somewhat less than four years can be matched in peacetime experience (e.g., from 1933 to 1937). The recent increase is unusual in that it came not after a deep cyclical trough but after 1939, which cannot be described as a year of depression, for its levels of over-all output were somewhat above those of the imniediately preceding cyclical peak (1937).

g) Both the resource-input and the preferred final output estimates derived here increase from 1939 to 1941 as much as or somewhat more than from 1941 to the first half of 1943 (allowing for the somewhat shorter interval). In contrast, the Department of Commerce estimates of gross national product at constant prices (using either the Department's or our concept) increase from 1941 to the first half of 1943 about one and a half times more than from 1939 to 1941 (again allowing for the difference in the length of the two periods).

h) In both total input of resources and final output, the share of the war sector rises precipitously-from 1 or 2 per cent in 1939 to about 40 in the first half of 1943; the share of the nonwar sectors declines correspondingly. The ratios derived here of war production to national product at the final output level are lower than those based on Department of Commerce gross national product totals in 1939 prices (employing our concept): for the first half of 1943 the percentage accounted for by war production as measured here is 38 , compared with 49 for the Department's estimates modified to agree with our concept.

i) Between 1939 and 1941 the increase in the volume of resources devoted to war production or in the total of final products represented by the latter was merely a fraction (roughly one-third to four-tenths) of the increase in total resource-input or total final output. There was concurrently a substantial rise in resource-input or product-output represented by the flow of goods to consumers and nonwar capital formation. These conclusions are similar to those suggested by current dollar value totals and by the Department of Commerce gross national product totals at constant prices. 
j) In contrast, from 1941 to the first half of 1943 the increase in the volume of resources devoted to war production or in the total of final products represented by the latter was much greater than in total resource-input or total final output. Our estimates, in terms of either resources or final products, show that the rise in national product from 1941 to the first half of 1943 was somewhat less than onehalf of the rise in war production; the compensating changes are a marked decline in nonwar capital formation and a minor drop in the flow of goods to consumers. Thus at least one-half of the increase in war production was achieved by drafts upon nonwar capital formation and (to a very minor extent) upon the flow of goods to consumers.

k) This conclusion differs from that suggested either by the Department of Commerce totals in constant prices or by current dollar value totals. The former indicate an increase in gross national product from 1941 to the first half of 1943 equal to about seven-tenths of the increase in war production; thus only three-tenths of the latter is accounted for by a decrease in the nonwar sectors, largely nonwar capital formation. In current dollar values the increase in national product is nine-tenths of that in war outlay; and if the former is fully counted as a source of the latter, only one-tenth of the greater outlay on war production was obtained through contraction of the nonwar sectors. Thus our estimates, which tend to 'deflate' war production to terms comparable with nonwar output, indicate for the period 1941 to the first half of 1943 a greater dependence of the rise in the war sector upon contraction in the nonwar sectors, and relatively less dependence upon the rise in total national product.

It would be superfluous to labor the significance of the conclusions suggested by our estimates; and of the difference between them and those suggested by current dollar value totals or estimates based on the more orthodox price adjustment followed by the Department of Commerce. They clearly affect our understanding of the over-all changes in the output of the economy and in its apportionment between the nonwar and war sectors during recent years. Nor is it neces. sary to stress the importance of such conclusions to any view of the capacity of the economy and of problems of postwar development.

This bearing of the analysis upon the understanding of changes in the economic scene in wartime justifies the attempt made here to derive estimates, despite the obvious difficulties and the necessity of resorting to assumptions that may well be questioned. The tentative 
character of our assumptions and the resulting qualifications upon the estimates have been repeatedly stressed. One may add merely that the analysis should be viewed as an illustrative methodological exploration. Certainly, the problem raised here is important whether the quantitative estimates are close approximations or not.

\section{APPENDIX}

\section{Derivation of Quarterly Totals in 1939 Prices}

\section{FLOW OF GOODS TO CONSUMERS}

The basic data are those of the Department of Commerce on consumers' outlay. The annual estimates of consumers' outlay in 1939 dollars are augmented by $\$ 3.1$ billion, the prewar total of direct taxes.

The Department of Commerce adjustment for price changes consists largely in reweighting the BLS prices of consumers" commodities and services. The over-all index differs little from the BLS cost of living index. ${ }^{1}$ We attempted to improve the adjustment in two ways: (a) for food and clothing, by comparing the 'deflated' totals derived by the Department of Commerce with measures of the physical volume of commodity flow; (b) for services, by reweighting the available price series.

\section{a Food and Clotbing}

For about 75 food items, representing more than 95 per cent by value of all foods purchased by civilians, the Food Distribution Administration has estimated the amount flowing into civilian channels, i.e., atter allowance for military takings and net exports. These items were weighted by consumers' expenditures in 1941. Since no data are available for 1939 we could not check for an upward bias in consumers' expenditures in 1939-41. The weighted FDA estimates were therefore linked to the estimate of deflated expenditures for 1941. giving an estimate of expenditures in constant prices 4 and 9 per cent lower than that of the Department of Commerce for 1942 and the first half of 1943 , respectively.

It is unlikely that inventory changes can account for any considerable part of these differences. The FDA consumption estimates allow for inventory changes at the early stages of the distribution process, and the rather sketchy data on retail inventories indicate no significant 1 See Price Deflators for Consumer Commodities and Capital Equipment, 1929-42, by Henry Shavell, Survey of Current Business, May 1943, op. 13-21. 
amount of liquidation in either 1942 or the first half of 1943. Nor could a higher degree of fabrication account for an accelerated upward movement in consumers' expenditures. Military and lend-lease takings, heavily weighted with highly processed items, are sufficient to explain the slightly greater employment in the processing industries in 1942 and 1943.

The price-adjusted totals for clothing could be checked with the help of the Federal Reserve Board index of the output of clothing and shoes for civilians; raw materials allocated to civilian output; military takings; and man hours of employment in apparel industries. The consensus of these data indicates a substantial overestimate in dollar expenditures, when adjusted by current price indexes for clothing and shoes, of roughly 15 per cent in 1942 and the first half of 1943 , even after adjustment for discrepancies that might be attributed to a reduction in inventories. ${ }^{2}$

\section{Services}

In studying price changes in the consumers' services area, we divided services into three groups: (i) those whose prices have always been closely regulated or have recently come under effective controlutilities on the one hand, rents on the other; (ii) those whose prices are still completely uncontrolled-recreation and amusement, personal services, domestic service; (iii) service payments that represent charges under relatively fixed obligations such as insurance premiums and society dues. The Department of Commerce adjustment consists in applying a price aggregate representing the service components of the BLS cost of living index, and dominated by regulated services. which had a weight of two-thirds as compared with a weight of less than one-half in the service expenditure estimates (at current prices). There is little reason to expect that price increases would be appreciably less for uncontrolled services than for commodities, since the same factors tend to inflate prices-high consumer incomes, labor shortages, rising costs of operation-and are not restrained by price ceilings. Similarly for the more or less fixed service payments, a general correction for the purchasing power of the dollat is in order. In the minor item of contributions to charity, the current dollar value must be adjusted for changes in costs and in the real content of the disbursements made possible by such contributions.

2 Because of the confidential classification of the underlying data, the detailed calcula. tions cannot be shown here. 
The adjustment for changes in the prices of the services group consists merely in reweighting the BLS service itens and applying the indexes for the unregulated service items or the cost of living index to the services classified under (ii) and (iii) above (App. Table 1). The resultant price indexes may still be considered low, partly because of quality deterioration in such controlled items as rent and transportation, partly because the cost of living index has a downward bias (for present uses).

\section{APpendix TABle 1}

Price Indexes for Services, 1942-1943

\begin{tabular}{|c|c|c|c|c|}
\hline \multirow{3}{*}{ Areas covered by BLS } & \multirow{3}{*}{$\begin{array}{c}\text { DOLLAR } \\
\text { EXPENDITURES } \\
1942 \\
\text { (millions) }\end{array}$} & \multicolumn{3}{|c|}{$\begin{array}{c}\text { PRICE 1NDEX }(1939=100) \\
1943\end{array}$} \\
\hline & & 1942 & $\begin{array}{c}\text { Ist } \\
\text { quater }\end{array}$ & $\begin{array}{c}2 d \\
\text { quarter }\end{array}$ \\
\hline & & & & \\
\hline Regulated & 8,100 & 112.2 & 117.0 & 120.6 \\
\hline $\begin{array}{l}\text { Kegulated } \\
\text { Other areas }\end{array}$ & 13,075 & 102.6 & 102.8 & 102.8 \\
\hline Education \& religion & 1,325 & 102.6 & 102.8 & 102.8 \\
\hline Other gifts \& bequests & 350 & 117.7 & 122.7 & 124.9 \\
\hline Employment expense \& family business & 2,850 & 117.7 & 122.7 & 124.9 \\
\hline Balancing item & 1,900 & 112.2 & 117.0 & 120.6 \\
\hline All services & 27,600 & 107.4 & 109.7 & 111.0 \\
\hline
\end{tabular}

Expenditures data from Department of Commerce; indexes from Bureau of Labor Statistics. Regulated services index applied to 'education and religion', 'free' service index to balancing item, cost of living index to other components.

\section{$c$ Effect of Adjustments under $(a)$ and $(b)$}

Appendix Table 2 summarizes the effect of the adjustments just described on the estimates of flow to consumers (excluding direct taxes) in 1939 prices. It is not quite valid to interpret the adjustment in the food and clothing items as an adjustment of the price indexes alone. In that sense the implicit price index in line A-5 (and C-5) is too high; and correspondingly the estimates in current dollars (lines A-1 and $C$-1) perhaps too high. But since it is impossible to apportion the adjustment, it was simpler and probably more proper to attribute it to the bias in price rather than in current dollar value indexes.

\section{d Quarterly Totals}

The quarterly series on consumers' outlay, in 1939 prices, seasonally unadjusted, is from the Department of Commerce. Each downward adjustment for food, clothing, and total services for 1942 and the first half of 1943 (described under (a) and (b) above), was interpolated by quarters with the help of a free-hand curve. Subtraction of these quarterly adjustments from the quarterly series gave a single 
series of quarterly estimates of consumers' outlay in 1939 prices which was then corrected for seasonal variations by a simple index based on ratios to a moving four-quarters average. This seasonal correction seemed to yield better totals than the adjustment for separate components made by the Department of Commerce.

\section{Appendix TABLe 2}

Revised Estimates of Flow of Goods to Consumers, 1939 Prices

Compared with the Department of Commerce Estimates

(dollar figures in billions; base year for index, 1939)

1943
1 Ht
Half
(seasonally adj.
annual rate)

A Commodities

1 Department of Commerce

1 Total, current prices

54.4

60.8

2 Total, 1939 prices

43.4

45.2

3 Implicit price index $[(1 \div 2) \times 100]$

125.4

134.5

11 Our Estimates

4 Total, 1939 prices

41.5

42.1

5 Implicit price index $[(1 \div 4) \times 100]$

131.1

144.4

B Services

1 Department of Commerce

1 Total, current prices

27.6

28.9

2 Total, 1939 prices

26.3

27.2

3 Implicit price index

104.9

106.3

II Our Estimates

4 Total, 1939 prices

5 Implicit price index

25.7

26.2

107.4

110.3

C Total (excl. governmental services)

1 Department of Commerce

1 Total, current prices

82.0

89.7

2 Total, 1939 prices

69.7

72.4

3 Implicit price index

117.6

123.9

II Our Estimates

4 Total, 1939 prices

67.2

68.3

5 Implicit price index

122.0

131.3

Department of Commerce estimates in current prices from Survey of Current Business, Aug. 1943; estimates at 1939 prices provided by the Department.

\section{NONWAR CAPITAL FORMATION}

\section{a Gross}

The two major components of this total are private gross and government nonwar capital formation. Quarterly estimates of the former, in 1939 prices, are from the Department of Commerce. In this price adjustment, the Department uses indexes of construction costs, prices of capital equipment goods, prices of commodities (in connection with the inventory changes), and so on. The methods are briefly 
described in the Survey of Current Business, March 1943 (notes to Tabie 1, pp. 19-20).

To this series we added quarterly estimates of nonwar government construction, breaking down the annual totals on the basis of series available at both the Department of Commerce and the War Production Board; and adjusting the current dollar values for price changes by the Department of Commerce index for its construction component of private gross capital formation. The result was a quarterly, seasonally unadjusted, series of gross nonwar capital formation.

A simple seasonal correction was then applied separately to the net inventory change and the other (largely construction and machinery) components of the total. The seasonal indexes were based on either absolute or relative deviations from a moving four-quarters average.

\section{$b \mathrm{Net}$}

Net was derived from gross by subtracting estimated depreciation and depletion. The annual totals of the latter, in current prices (Table 1 , line 9), were interpolated by quarters with the help of a free-hand curve. The adjustment for price changes was then made by an index derived from the Department of Commerce data for the construction and durable equipment components of private gross capital formation. Since current price changes are presumably damped in the total values of capital goods subject to depreciation and depletion, only one-half of the price rise in the current prices of construction and equipment was allowed in the index used.

This procedure is crude. The proper method calls for an adjustment, first, of depreciation charges for the difference between original cost and reproduction value bases; then for a more accurate measurement of changes in reproduction values. Also, the quarterly interpolation is approximate. But in view of the difficulties of a proper translation of the depreciation estimates to a reproduction value base, the small annual change, and the smallness of the item relative to the national product totals, it did not seem advisable to attempt the
more laborious calculations.

\section{WAR OUTLAY}

The general scheme of deriving war outlay in 1939 prices is indicated in Appendix Table 3; some of the underlying data are presented in 
Appendix Table 4. Because data on the components of war outlay are confidential, no specific entries are shown in Appendix Table 3.

\section{Appendix Table 3}

Schematic Presentation of Derivation of War Outlay in 1939 Prices 1939,1940 , first half of 1941 ; then by quarters

1 Total war outlay, current dollars

2 Munitions \& war construction (varying \% of line 1, averaging 25 since 1940)

3 Nonmunitions (line 1-line 2)

4 Total costs, munitions \& war construction

a) Labor (line $2 \times$ line 5 of $\Lambda$ pp. Table 4 )

b) Capital $\&$ enterprise (line $2 \times$ line 6 of App. Table 4 )

c) Taxes (line $2 \times$ line 7 of App. Table 4)

5 Price index for labor costs (see text)

6 Price index for capital \& enterprise (line 10 of App. Table 4)

7 Resource costs, 1939 prices

a) Labor (line $4 a \div$ line 5 )

b) Capital $\&$ enterprise (line $4 b \div$ line 6 )

c) Taxes (1939 ratio of line 3 to sum of lines $1 \& 2$ in App. Table 4, multiplied by sum of line $7 \mathrm{a} \&$ line $7 \mathrm{~b}$ )

d) Total (line $7 a+$ line $7 b+$ line $7 c$ )

8 Price index for nonmunitions (see text)

9 Nonmunitions, 1939 prices (line $3 \div$ line 8 )

10 War outlay, 1939 prices (line $7 \mathrm{~d}+$ line 9)

Implicit Price Indexes

11 Taxes (line $4 \mathrm{c} \div$ line $7 \mathrm{c}$ )

12 Munitions \& war construction (line $2 \div$ line $7 d$ )

13 Total war outlay (line $1 \div$ line 10 )

The adjustment of war outlay for price changes begins with a breakdown into two parts, for which separate adjustment must be made: (a) nonmunitions; (b) munitions plus war construction. With quarterly data in current prices, which need no seasonal adjustment, at hand, derivation of appropriate price indexes leads directly to calculating quarterly totals in 1939 prices. The sole remaining step necessary to derive the proper component for national income (as distinct from the component for gross national product) is (c) to subtract quarterly estimates of depreciation on war construction, in 1939 prices.

\section{a Nonmunitions}

These comprise military pay; civilian pay (war agencies); subsistence; travel; clothing and personal equipment; agricultural exports; other nonmunitions. Apart from pay items, the group is made up largely of consumer-type goods, though in the case of clothing subject to considerable modification to satisfy military requirements. Many of the items, indeed, are purchased off the shelf rather than contracted for. Anyway, their close correspondence with civilian type 


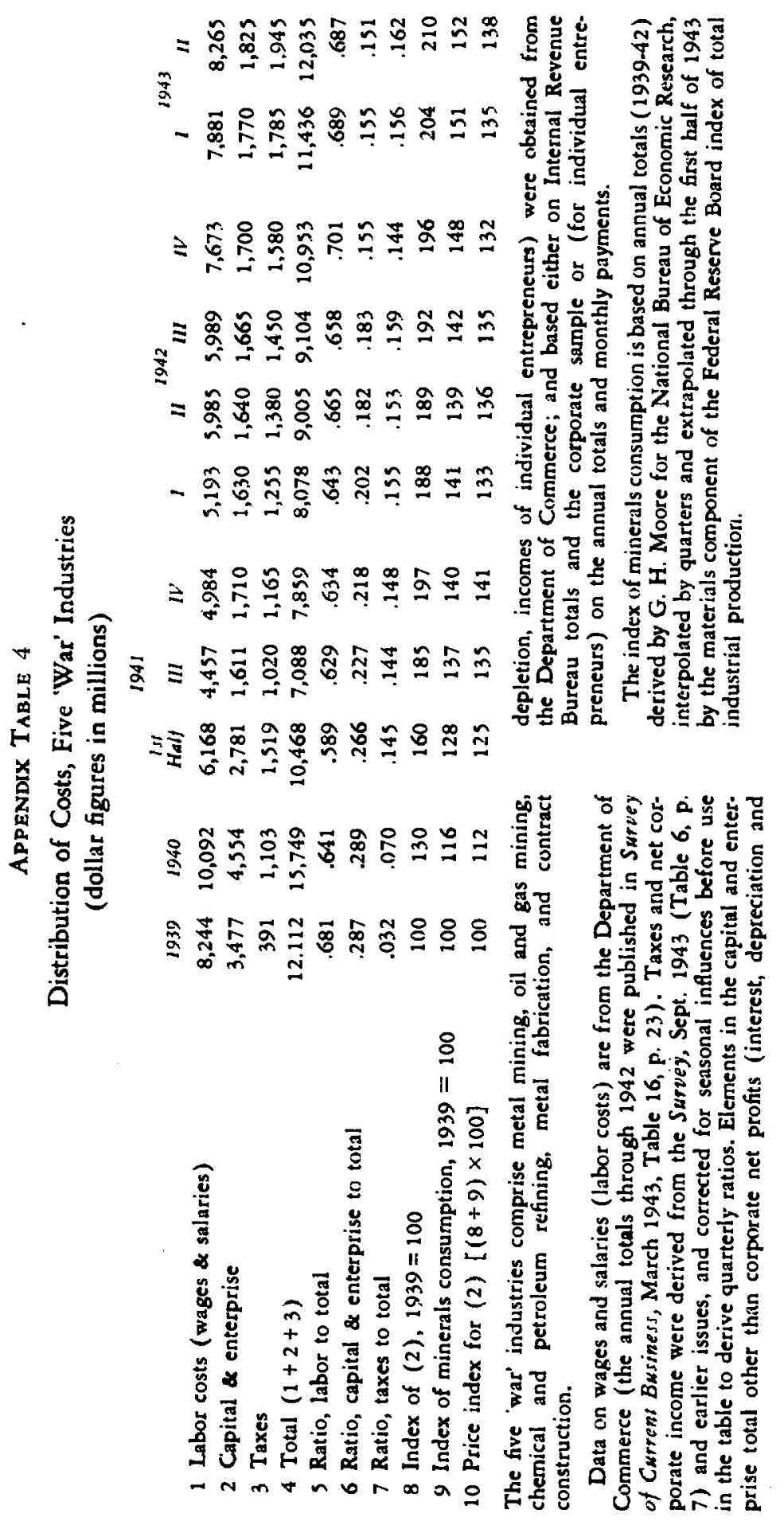


products would seem to warrant the application of wholesale price indexes. These were selected from the BLS wholesale price series. Both military and civilian pay were corrected for recent increases in rates of pay.

The total price index for this category rises to about 115 by the end of 1941; averages about 125 in 1942; and rises further to somewhat above 140 by the second quarter of 1943 .

\section{Munitions and $W$ ar Construction}

In the deflation of munitions and war construction we are forced to study the compensation of productive resources in order to measure physical output. The conversion to 1939 prices was effected by the separate deflation of the major components in the current price of munitions output: labor costs and gross profits, the latter in turn allocable between returns to capital and enterprise and corporate income and excess profits tax. The weights assigned to these three components of munitions output are determined by the breakdown of gross output in the five industrial groups (oil, gas and metal mining, chemicals and petroleum refining, metal fabrication, and contract 'construction) that accounted for the bulk of munitions production and war construction in 1942 (see App. Table 4).

i) The price index for the labor factor was derived from a study of changes in hourly earnings in war manufacturing industries. A weighted index was constructed by dividing aggregate weekly wages actually paid by aggregate weekly wages, assuming 1939 hourly earnings throughout the period, in a group of 44 war industries (using BLS employment and earnings series). This gave, in effect, an index of hourly earnings in these 44 industries combined, using current man hours as weights. ${ }^{3}$ Aggregate weekly wages used in this calculation were derived by multiplying the number of employees by the average work week (in hours), then multiplying the product (i.e., weekly man hours) by average hourly earnings.

The 44 metal, chemical, and rubber industries covered in this calculation, using the BLS designations and ranged in ascending order of percentage increase from 1939 to 1942 in average hourly earnings, follow.

3 Weighting this index of hourly earnings had almost no effect. The weighted and the unweighted inderes almost kept' pace during 1939-42; the high wage industries had a slight tendency to expand less rapidly than the relatively low wage industries. 
1 Communications equipment

2 Rubber tires $\&$ inner tubes

3 Blast furnaces, steel works \& rolling mills

4 Tractors

5 Stoves, oil burners \& heating equipment

6 Plumbers" supplies

7 Wirework

8 Automobiles

9 Textile machinery

10 Machine-tool accessories

11 Washing machines, wringers \& driers, domestic

12 Lighting equipment

13 Chemicals

14 Sewing machines, domestic a industrial

15 Explosives \& safety fuses

16 Fabricated structural \& ornamental metal work

17 Typewriters

18 Cash registers, adding \& calculating machines

19 Machinery \& machine-shop products

20 Machine tools

21 Bolts, nuts, washers, rivets
22 Silverware \& plated ware

23 Smelting \& refining, nonferrous metals

24 Electrical equipment

25 Hardware

26 Rubber goods, other

27 Agricultural machinery, excl. tractors

28 Stamped \& enameled ware \& galvanizing

29 Aircraft \& parts, excl. aircraft engines

30 Steam \& hot-water heating apparatus \& steam fittings

31 Cutlery \& edge tools

32 Clocks \& watches

33 Tools, excl. edge tools, machine tools, files \& saws

34 Aluminum

35 Car building, electric \& steam railroad

36 Radios \& phonographs

37 Forgings, iron \& steel

38 Alloying \& rolling \& drawing

39 Ammunition, smail arms

40 Shipbuilding

41 Engines \& turbincs

42 Pumps \& pumping equipment

43 Locomotives

44 Aireraft engines

ii) The current cost of the capital plus enterprise factor was measured as the sum of corporate net income after taxes, depreciation, entrepreneurial income, interest, and net rents and royalties. To derive a price index for this component, recent increases in the total cost had to be related to number of units of capital and enterprise. Since it is difficult to find an index of changes in the input of capital and enterprise analogous to man hours of employment, we used an index representing the consumption of raw materials of mineral origin."

4 Prepared at the National Bureau of Economic Research by G. H. Moore. It is a weighted index comprising nine metals and ten nonmetals:

\section{Metals}

Ferrous

Steel ingots \& castings

Nonferrous

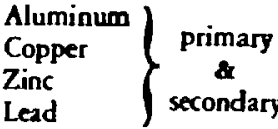

Tin ronsumption

Magnesium

Antimony consumption

Mercury Consumption

\section{Nonmetals}

Frels

Anthracite coal

Bituminous coal

Crude petroleum

Natural gas

Other nonmesals

Portland cement shipments

Gypsum

Graphite

Sand \& gravel

Crushed limestone

Sulphur 
It may reflect with a fair degree of accuracy the utilization of durable capital in the war industries which are by and large the metal consuming industries in both war and peace; but is quite unrelated to the enterprise or risk element of gross capital or to such elements of management as are not included in labor incomes. The unit return to capital and enterprise shows a net increase only slightly greater than that shown by the unit return to labor. This is not believed to be excessively large and may conceal a sizable downward bias.

ii) Corporate income and excess profits taxes have increased enormously since 1939, particularly in the industries that have been largely converted to war output. But the increase reflects the needs of the government for more revenue in wartime rather than additional services performed for corporate enterprises. It can of course be argued that under wartime controls of production and distribution the government has assumed most of the risk and many of the management functions of corporations, particularly of those producing military equipment. But to the extent that this is true, the increase in the real contribution of capital and enterprise is certainly overstated in our estimates; and any allowance for an increase in the real value of services represented by taxes would be compensated by a corresponding reduction in the estimate of the real value of the services of capital and enterprise. We therefore assumed that in 1939 corporate taxes were the monetary equivalent of the federal government's contribution to business activity; and that thereafter such services kept pace with real output, i.e., with deflated labor and capital costs. As a result, corporate taxes have an implicit price index of nearly 700 in 1942 and are an important factor in raising the implicit index for all war outlays for that year.

For both munitions and war construction and nonmunitions, the attempt to get quarterly price indexes based on these detailed calculations did not seem warranted for the period before the third quarter of 1941 , partly because prices had changed so little since 1939, but largely because the war outlay totals were so small. From 1939 to the third quarter of 1941 annual data were, therefore, used and the quarterly price indexes derived by graphic interpolation (App. Table 5).

\section{(Nore 4 cond.)}

Experiments with an index of somewhat different composition more closely related to the fve 'war' industries (excluding coal and including rubber, ethyl alcohol, lumber) yielded a similar index. Recalculation did not, therefore, seem warranted. 


\section{APPENDIX TABLE 5}

Derivation of Quarterly War Outlays and Price Index 1939 to Second Quarter of 1941

(dollar figures in billions)

\begin{tabular}{|c|c|c|c|c|c|c|}
\hline \multirow[b]{2}{*}{$\begin{array}{c}\text { YRAR } \\
\text { AND } \\
\text { QUARTER }\end{array}$} & \multicolumn{2}{|c|}{ WAK OUTLAY } & \multicolumn{3}{|c|}{$\begin{array}{l}\text { INPLICIT PXICE 1NDEX } \\
(1939=100) \\
\text { Interpaleted }\end{array}$} & \multirow[b]{2}{*}{$\begin{array}{c}\text { wal OUTLAY } \\
\text { (1939 prices) } \\
\text { (6) }\end{array}$} \\
\hline & $\begin{array}{c}\text { Carrent } \\
\text { prives } \\
\text { (1) }\end{array}$ & $\begin{array}{c}1939 \\
\text { prrces } \\
(2)\end{array}$ & $\begin{array}{c}\text { Actalal } \\
\text { (3) }\end{array}$ & $\begin{array}{l}\text { Inirrpolated } \\
\text { ralmes } \\
\text { (4) }\end{array}$ & $\begin{array}{l}\text { Simat } \\
\text { series } \\
\text { (3) }\end{array}$ & \\
\hline $\begin{array}{r}1939 \\
1 \\
\text { II } \\
\text { III } \\
\text { IV }\end{array}$ & $\begin{array}{r}1.4 \\
.3 \\
.3 \\
.4 \\
.4\end{array}$ & 1.4 & 100 & & 100 & $\begin{array}{r}1.4 \\
.3 \\
.3 \\
.4 \\
.4\end{array}$ \\
\hline $\begin{array}{r}1940 \\
\text { I } \\
\text { II } \\
\text { III } \\
\text { IV }\end{array}$ & $\begin{array}{r}2.7 \\
.4 \\
.5 \\
.6 \\
1.2\end{array}$ & 2.4 & 112 & $\begin{array}{l}103 \\
108 \\
110 \\
115\end{array}$ & $\begin{array}{l}112 \\
103 \\
108 \\
115 \\
115\end{array}$ & $\begin{array}{r}2.4 \\
.4 \\
.5 \\
.5 \\
1.0\end{array}$ \\
\hline $\begin{array}{r}1941 \\
\text { II } \\
\text { III }\end{array}$ & $\begin{array}{r}12.5 \\
1.9 \\
2.5 \\
3.4 \\
4.7\end{array}$ & $\begin{array}{l}2.66 \\
3.52\end{array}$ & $\begin{array}{l}128 \\
133\end{array}$ & $\begin{array}{l}120 \\
124\end{array}$ & $\begin{array}{l}128 \\
120 \\
124 \\
128 \\
133\end{array}$ & $\begin{array}{l}9.8 \\
1.6 \\
2.0 \\
2.7 \\
3.5\end{array}$ \\
\hline $\begin{array}{r}1942 \\
\text { I } \\
\text { II } \\
\text { III } \\
\text { IV }\end{array}$ & $\begin{array}{r}49.3 \\
6.9 \\
10.4 \\
14.3 \\
17.7\end{array}$ & $\begin{array}{r}33.7 \\
5.07 \\
7.26 \\
9.48 \\
11.80\end{array}$ & $\begin{array}{l}146 \\
136 \\
143 \\
151 \\
150\end{array}$ & & $\begin{array}{l}146 \\
136 \\
143 \\
151 \\
150\end{array}$ & $\begin{array}{r}33.7 \\
5.1 \\
7.3 \\
9.5 \\
11.8\end{array}$ \\
\hline 1943 & & & & & & \\
\hline II & $\begin{array}{l}18.8 \\
21.8\end{array}$ & $\begin{array}{l}12.30 \\
13.95\end{array}$ & $\begin{array}{l}153 \\
156\end{array}$ & & $\begin{array}{l}153 \\
156\end{array}$ & $\begin{array}{l}12.3 \\
14.0\end{array}$ \\
\hline
\end{tabular}

Col. 1: From Department of Commerce.

Col. 2: By application to Col. 1 of annual and quarterly price indexes in Appendix
Table 3. Col. 3: Col. $1 \div$ Col. 2 .

Col. 4: Interpolated graphically on the basis of annual figures. There was no need to interpolate quarterly for 1939 since the indicated quarterly indexes were not sufficiently above or below 100 to affect the current dollar figures in the first decimal place.

Col. 5: Combination of Col. 3 and 4.

Col. 6: Col. 2 when given; for all other periods (Col. $1 \div$ Col. 5) $\times 100$

\section{c Depreciation on War Construction}

The annual totals in current prices, based on the changing cost of war construction (Table 1), were apportioned by quarters in rough correspondence to the quarterly volumes of new war construction (data available at the War Production Board). To adjust these quarterly totals for price changes we took the index of construction costs and 
prices of durable equipment used by the Department of Commerce for the construction and equipment components of private gross capital formation. It undoubtedly understates the level of current costs of war construction relative to 1939, but may approximate fairly well the changing valuation level in the cumulative total of war construction subject to depreciation. In any event, in view of the necessarily crude assumptions that have to be made with reference to the scope of this category and the life period underlying the depreciation rate, more laborious and specific procedures for price adjustment did not seem warranted.

\section{SUMMARY, SECTIONS 1-3}

To summarize the price adjustments and quarterly interpolations

\section{APPENDXX TABle 6}

National Product and Its Components, Wartime Concept

Quarterly, 1939-1943, Current Prices (billions of dollars, seasonally adjusted annual rates)

\begin{tabular}{|c|c|c|c|c|c|c|c|}
\hline \multirow{3}{*}{$\begin{array}{c}\text { YEAR } \\
\text { AND } \\
\text { QUTARTER }\end{array}$} & \multirow{3}{*}{$\begin{array}{c}\text { FLOW OF } \\
\text { COOOS TO } \\
\text { CONSUMERS } \\
\text { (1) }\end{array}$} & \multicolumn{2}{|c|}{ HONVAR } & \multicolumn{2}{|c|}{ TAR OUTLAY } & \multicolumn{2}{|c|}{ NATIONAL PRODHCT } \\
\hline & & $\begin{array}{c}\text { Capital } \\
\text { Gross }\end{array}$ & $\begin{array}{l}\text { MMAITON } \\
\text { Nef }\end{array}$ & $\begin{array}{l}\text { Thil } \\
\text { Gross }\end{array}$ & $\begin{array}{l}\text { TLAY } \\
\text { Net }\end{array}$ & $\begin{array}{c}\text { Grois } \\
(\mathrm{i}+2+4\end{array}$ & $\begin{array}{c}\text { Nef } \\
(+3+3)\end{array}$ \\
\hline & & (2) & (3) & (4) & (3) & (6) & (7) \\
\hline 1939 & 64.8 & 13.2 & 6.0 & 1.4 & 1.4 & 79.4 & 72.2 \\
\hline I & 63.5 & 12.4 & 5.3 & 1.2 & 1.2 & 77.1 & 70.0 \\
\hline II & 64.1 & 11.6 & 4.4 & 1.3 & 1.3 & 77.0 & 69.8 \\
\hline III & 65.1 & 12.7 & 5.5 & 1.4 & 1.4 & 79.2 & 72.0 \\
\hline IV & 66.3 & 16.2 & 8.9 & 1.5 & 1.5 & 84.0 & 76.7 \\
\hline 1940 & 68.8 & 16.6 & 9.2 & 2.7 & 2.7 & 88.1 & 80.7 \\
\hline I & 67.7 & 16.4 & 9.1 & 1.7 & 1.7 & 85.8 & 78.5 \\
\hline II & 68.1 & 14.7 & 7.3 & 2.0 & 2.0 & 84.8 & 77.4 \\
\hline III & 69.0 & 16.5 & 9.1 & 2.5 & 2.5 & 88.0 & 80.6 \\
\hline IV & 70.3 & 18.8 & 11.3 & 4.7 & 4.6 & 93.8 & 86.2 \\
\hline 1941 & 77.7 & 21.0 & 13.1 & 12.5 & 12.2 & 111.2 & 103.0 \\
\hline I & 74.1 & 19.2 & 11.6 & 7.6 & 7.4 & 100.9 & 93.1 \\
\hline II & 76.8 & 20.9 & 13.1 & 10.0 & 9.7 & 107.7 & 99.6 \\
\hline III & 80.4 & 21.3 & 13.3 & 13.6 & 13.2 & 115.3 & 106.9 \\
\hline IV & 79.5 & 22.3 & 14.1 & 18.8 & 18.3 & 120.6 & 111.9 \\
\hline 1942 & 85.1 & 9.3 & 0.5 & 49.3 & 48.0 & 143.7 & 133.6 \\
\hline I & 83.4 & 14.9 & 6.4 & 27.7 & 27.0 & 126.0 & 116.8 \\
\hline II & 82.6 & 12.7 & 4.0 & 41.5 & 40.4 & 136.8 & 127.0 \\
\hline III & 85.9 & 7.2 & -1.7 & 57.1 & 55.6 & 150.2 & 139.8 \\
\hline IV & 88.5 & 2.1 & -6.9 & 70.9 & 69.1 & 161.5 & 150.7 \\
\hline 1943 (1st balf) & 92.8 & -0.1 & -9.1 & 81.0 & 78.9 & 173.7 & 162.6 \\
\hline 1 & 93.3 & 0.2 & -8.8 & 75.0 & 73.0 & 168.5 & 157.5 \\
\hline 11 & 92.3 & -0.5 & -9.5 & 87.1 & 84.9 & 178.9 & 167.7 \\
\hline
\end{tabular}

Owing to rounding, quarterly totals may not add up exactly. 
described so far, Appendix Tables 6 and 7 bring together the estimates of national product and its components, at current and 1939 prices.

\section{APpendix TABLE 7}

National Product and Its Components, Wartime Concept, Quarterly, 1939-43 1939 Prices, Mixed Final Product and Resource-Input Levels

\begin{tabular}{|c|c|c|c|c|c|c|c|}
\hline \multirow{3}{*}{$\begin{array}{c}\text { YEAR } \\
\text { AND } \\
\text { QUARTER }\end{array}$} & \multirow{3}{*}{$\begin{array}{l}\text { FLOW OF } \\
\text { GOODS TO } \\
\text { rONSUMEES } \\
\text { (1) }\end{array}$} & \multicolumn{2}{|c|}{ NONWAR } & \multirow{2}{*}{\multicolumn{2}{|c|}{ WAR OUTLAY }} & \multicolumn{2}{|c|}{ NATIONAL PLODUCT } \\
\hline & & CAPltal & DRMATION & & & Gross & Net \\
\hline & & $\begin{array}{c}\text { Gross } \\
\text { (2) }\end{array}$ & $\begin{array}{l}\text { Net } \\
\text { (3) }\end{array}$ & $\begin{array}{c}\text { Gross } \\
\text { (4) }\end{array}$ & $\begin{array}{l}N a t \\
(5)\end{array}$ & $(1+2+4)$ & $\begin{array}{c}(1+3+5) \\
(7)\end{array}$ \\
\hline 1939 & 64.8 & 13.2 & 6.0 & 1.4 & 1.4 & 79.4 & 72.2 \\
\hline I & 62.8 & 12.0 & 4.9 & 1.2 & 1.2 & 76.0 & 68.9 \\
\hline II & 65.2 & 11.3 & 4.1 & 1.3 & 1.3 & 77.8 & 70.6 \\
\hline III & 64.8 & 12.9 & 5.7 & 1.4 & 1.4 & 79.1 & 71.9 \\
\hline IV & 66.4 & 16.6 & 9.3 & 1.5 & 1.5 & 84.5 & 77.2 \\
\hline 1940 & 68.2 & 16.4 & 9.0 & 2.4 & 2.4 & 87.0 & 79.6 \\
\hline I & 66.5 & 16.3 & 9.1 & 1.7 & 1.7 & 84.5 & 77.3 \\
\hline II & 67.7 & 15.7 & 8.3 & 2.0 & 2.0 & 85.4 & 78.0 \\
\hline III & 68.5 & 16.7 & 9.3 & 2.0 & 2.0 & 87.2 & 79.8 \\
\hline IV & 70.1 & 16.8 & 9.4 & 4.0 & 3.9 & 90.9 & 83.4 \\
\hline 1941 & 73.1 & 19.5 & 11.9 & 9.8 & 9.5 & 102.4 & 94.5 \\
\hline I & 70.9 & 19.2 & 11.7 & 6.4 & 6.2 & 96.5 & 88.8 \\
\hline II & 74.1 & 21.4 & 13.8 & $\mathbf{8 . 0}$ & 7.7 & 103.5 & 95.6 \\
\hline III & 74.9 & 19.9 & 12.2 & 10.6 & 10.2 & 105.4 & 97.3 \\
\hline IV & 72.7 & 17.7 & 9.9 & 14.2 & 13.7 & 104.6 & 96.3 \\
\hline 1942 & 70.2 & 8.3 & 0.0 & 34.0 & 32.9 & 112.5 & 103.1 \\
\hline I & 70.7 & 14.0 & 6.0 & 20.2 & 19.6 & 104.9 & 96.3 \\
\hline II & 68.7 & 13.6 & 5.4 & 29.6 & 28.6 & 111.9 & 102.7 \\
\hline III & 69.9 & 5.6 & -2.7 & 38.4 & 37.1 & 113.9 & 104.3 \\
\hline IV & 71.5 & 0.0 & -8.4 & 47.7 & 46.1 & 119.2 & 109.2 \\
\hline 1943 (1sf balf) & 71.3 & 0.4 & -7.9 & 52.0 & 50.2 & 123.7 & 113.6 \\
\hline I & 71.1 & 0.3 & -8.1 & 48.9 & 47.1 & 120.3 & 110.1 \\
\hline II & 71.5 & 0.5 & -7.8 & 55.2 & 53.3 & 127.2 & 117.0 \\
\hline
\end{tabular}

Owing to rounding, quarterly totals may not add up exactly.

The seasonal adjustments used for this table are different from those used for Appendix Table 6.

The seasonal adjustments applied to the totals in current prices are those used by the Department of Commerce. The seasonal correction of the components in 1939 prices is by a simple method, described above, which yields a more acceptably smooth movement of the totals. For this and other reasons, one cannot derive quarterly implicit price indexes by comparing quarterly entries in the two tables. Comparison of the annual totals is more legitimate, except that for flow of goods to consumers it should be made after the constant absolute 
addition of direct taxes has been subtracted from Column 1 (in both tables).

The main difficulty with the results attained so far is that the indexes used to measure price changes for goods included under flow to consumers, nonwar capital formation, and the nonmunitions part of war outlay, relate to final products; whereas those used to 'deflate' current dollar values of munitions and war construction relate to resources. Thus, one part of the national product, when adjusted for price changes, represents a sum of final products at their 1939 prices; the other is a sum of productive resources valued at their 1939 prices. The two parts, which were in fact added in Appendix Table 7, can legitimately be added only by one of two further steps: either final product totals have to be converted to totals of resource-input or resource-input converted to final product output.

\section{TRANSITION TO RESOURCE-INPUT}

Except for scattered data on changes in physical output per man hour for a few manufacturing and mining industries and utilities (published chiefly hy the Bureau of Labor Statistics, Productivity and Technological Development Division), there is no information on changes in the efficiency of resources in production involved in the flow of goods to consumers, nonwar capital formation, or the flow of nonmunitions. But whatever data there are suggest that the gain in productivity since 1939 has been moderate, not more than 2 or 3 per cent per year; that it virtually ceased by 1942; and that in recent quarters, as the scale of operations in many civilian industries declined and dilution of labor and other resources took place, efficiency per resource unit may have declined slightly.

The index in Column 1 of Appendix Table 8 is an unwarrantedly precise quantitative expression of these impressions: it is intended to be illustrative rather than substantive. It is applied uniformly to the three major components in national product which in Appendix Table 7 are measured at 1939 final product prices: consumers' outlay; nonwar construction and equipment; nonmunitions. Instead of converting the price indexes used for Appendix Table 7 into indexes of resource prices, then using the latter to adjust the current dollar value totals in Appendix Table 6, we calculated directly the adjustments that would have to be made in the totals in Appendix Table 7 in order to get the results of correcting current dollar values by indexes of compensation of resources. 


\section{APpendix TABLE 8}

Calculation of Adjustments in Appendix Table 7 for

Translating Totals to Resource-Input Levels, 1939 Prices

(billions of dollars, seasonally adjusted annual rates)

\begin{tabular}{|c|c|c|c|c|c|c|c|}
\hline $\begin{array}{c}\text { YEAR } \\
\text { AND } \\
\text { QUAATER }\end{array}$ & $\begin{array}{l}\text { EFFICIENCY } \\
\text { INDEX } \\
\text { (1) }\end{array}$ & $\begin{array}{l}\text { FLOW TO } \\
\text { CONsunERS } \\
\text { (excl.) } \\
\text { gor. } \\
\text { serrices) } \\
\text { (2) }\end{array}$ & $\begin{array}{l}\text { ADJ. } \\
\text { IN } \\
(2) \\
(3)\end{array}$ & $\begin{array}{l}\text { NONVAR } \\
\text { CONSTRLC. } \\
\text { TION } \\
\text { EQUIPUENT } \\
\text { (4) }\end{array}$ & $\begin{array}{l}\text { ADJ. } \\
\text { IN } \\
(4) \\
(5)\end{array}$ & $\begin{array}{l}\text { ASSUMEI } \\
\text { NONMU } \\
\text { N1T1ONS } \\
(6)\end{array}$ & $\begin{array}{c}\text { ADJ. } \\
\text { iN } \\
(6) \\
(7)\end{array}$ \\
\hline 1939 & 100.0 & 61.7 & 0.0 & 11.4 & 0.0 & & \\
\hline 1 & 99.1 & 59.7 & +0.5 & 11.1 & +0.1 & \multirow{3}{*}{\multicolumn{2}{|c|}{ No }} \\
\hline 11 & 99.7 & 62.1 & +0.2 & 11.2 & 0.0 & & \\
\hline 111 & 100.3 & 61.7 & -0.2 & 11.3 & 0.0 & & \\
\hline IV & 100.9 & 63.3 & -0.6 & 12.1 & -0.1 & \multicolumn{2}{|c|}{ adjustment } \\
\hline 1940 & 102.5 & 65.1 & -1.6 & 13.0 & -0.4 & \multirow{2}{*}{\multicolumn{2}{|c|}{ through }} \\
\hline I & 101.5 & 63.4 & -0.9 & 12.1 & -0.2 & & \\
\hline 11 & 102.2 & 64.6 & -1.4 & 12.6 & -0.3 & \multirow{2}{*}{\multicolumn{2}{|c|}{1940}} \\
\hline III & 102.8 & 65.4 & -1.8 & 13.1 & -0.4 & & \\
\hline IV & 103.4 & 67.0 & -2.2 & 14.0 & -0.5 & & \\
\hline 1941 & 104.8 & 70.0 & -3.2 & 15.3 & -0.7 & 2.9 & -0.2 \\
\hline 1 & 104.0 & 67.8 & -2.6 & 15.4 & -0.6 & 1.9 & -0.1 \\
\hline Il & 104.6 & 71.0 & -3.1 & 16.2 & -0.7 & 2.4 & -0.1 \\
\hline 111 & 105.1 & 71.8 & -3.5 & 14.7 & -0.7 & 3.2 & -0.2 \\
\hline IV & 105.5 & 69.6 & -3.6 & 15.0 & -0.8 & 4.3 & -0.3 \\
\hline 19.42 & 105.1 & 67.1 & -3.3 & 8.3 & -0.4 & 10.2 & -0.5 \\
\hline 1 & 105.3 & 67.6 & -3.4 & 11.3 & -0.6 & 6.1 & -0.3 \\
\hline II & 105.1 & 65.6 & -3.2 & 9.5 & -0.3 & 8.9 & -0.4 \\
\hline 111 & 105.0 & 66.8 & -3.2 & 7.0 & -0.3 & 11.5 & -0.6 \\
\hline IV & 105.0 & 68.4 & -3.2 & 5.3 & -0.3 & 14.3 & -0.7 \\
\hline 1943 (1st balf) & ) 105.0 & 68.2 & -3.2 & 3.8 & -0.2 & 15.6 & -0.7 \\
\hline I & 105.0 & 68.0 & -3.2 & 4.2 & -0.2 & 14.7 & -0.7 \\
\hline II & 105.0 & 68.4 & -3.2 & 3.5 & -0.2 & 16.6 & -0.8 \\
\hline
\end{tabular}

Col. 1: assumed, see text.

Col. 2: Col. 1 of Appendix Table 7 minus direct taxes.

Col. 3: Col. 2-100 (Col. 2/Col. 1).

Col. 4: Department of Commerce data.

Col. 5: Col. 4- 100 (Col. 4/Col. 1 ).

Col. 6: Col. 4 of Appendix Table 7 multiplied by 0.3 .

Col. 7: Col. 6-100 (Col. 6/Col. 1).

The adjustment yields new totals of national product and its components (App. Table 9). The meaning of these estimates should be kept clearly in mind: they gauge the volume of resource-input at their prices (i.e., their relative efficiency levels) in 1939 on the assumption that resources used in munitions and war construction are comparable in relative efficiency with those utilized in the five 'war' industries in 1939. This assumption is especially important, since unless we make it we cannot add munitions and construction, adjusted by indexes of resource prices in the five 'war' industries, to other parts of national product, adjusted by derived indexes of resource prices on a 1939 base. 


\section{APPENDIX TABLE 9}

National Product and Its Components, Wartime Concept Quarterly, 1939-1943, 1939 Prices, Resource-Input Levels (billions of dollars, seasonally adjusted annual rates)

\begin{tabular}{|c|c|c|c|c|c|c|c|}
\hline YEAR & & & Wal & & & NATIONAI & PLOOUCT \\
\hline $\begin{array}{l}\text { AND } \\
\text { QUARTER }\end{array}$ & $\begin{array}{l}\text { GOODS TO } \\
\text { ronsumess } \\
\text { (1) }\end{array}$ & $\begin{array}{c}\text { CAPTTAL } \\
\text { Grass } \\
\text { (2) }\end{array}$ & $\begin{array}{l}\text { OEMATION } \\
\text { Net } \\
\text { (3) }\end{array}$ & $\begin{array}{c}\text { WAR } \\
\text { Gross } \\
\text { (4) }\end{array}$ & $\begin{array}{c}\text { TLAY } \\
\text { Net } \\
(3)\end{array}$ & $\begin{array}{c}\text { Grnss } \\
(1+2+4) \\
(6)\end{array}$ & $\begin{array}{c}\text { Net } \\
(1+3+3) \\
(7)\end{array}$ \\
\hline 1939 & 64.8 & 13.2 & 6.0 & 1.4 & 1.4 & 79.4 & 72.2 \\
\hline I & 63.3 & 12.1 & 5.0 & 1.2 & 1.2 & 76.6 & 69.5 \\
\hline HI & 65.4 & 11.3 & 4.1 & 1.3 & 1.3 & 78.0 & 70.8 \\
\hline III & 64.6 & 12.9 & 5.7 & 1.4 & 1.4 & 78.9 & 71.7 \\
\hline IV & 65.8 & 16.5 & 9.2 & 1.5 & 1.5 & 83.8 & 76.5 \\
\hline 1940 & 66.6 & 16.0 & 8.6 & 2.4 & 2.4 & 85.0 & 77.6 \\
\hline I & 65.6 & 16.1 & 8.9 & 1.7 & 1.7 & 83.4 & 76.2 \\
\hline II & 66.3 & 15.4 & 8.0 & 2.0 & 2.0 & 83.7 & 76.3 \\
\hline III & 66.7 & 16.3 & 8.9 & 2.0 & 2.0 & 85.0 & 77.6 \\
\hline IV & 67.9 & 16.3 & 8.9 & 4.0 & 3.9 & 88.2 & 80.7 \\
\hline 1941 & 69.9 & 18.8 & 11.2 & 9.6 & 9.3 & 98.3 & 90.4 \\
\hline I & 68.3 & 18.6 & 11.1 & 6.3 & 6.1 & 93.2 & 85.5 \\
\hline II & 71.0 & 20.7 & 13.1 & 7.9 & 7.6 & 99.6 & 91.7 \\
\hline III & 71.4 & 19.2 & 11.5 & 10.4 & 10.0 & 101.0 & 92.9 \\
\hline IV & 69.1 & 16.9 & 9.1 & 13.9 & 13.4 & 99.9 & 91.6 \\
\hline 1942 & 66.9 & 7.9 & -0.3 & 33.5 & 32.4 & 108.3 & 99.0 \\
\hline 1 & 67.3 & 13.4 & 5.4 & 19.9 & 19.3 & 100.6 & 92.0 \\
\hline II & 65.5 & 13.1 & 4.9 & 29.2 & 28.2 & 107.8 & 98.6 \\
\hline III & 66.7 & 5.3 & -3.0 & 37.8 & 36.5 & 109.8 & 100.2 \\
\hline IV & 68.3 & -0.3 & -8.7 & 47.0 & 45.4 & 115.0 & 105.0 \\
\hline 1943 (1st balf) & 68.1 & 0.2 & -8.1 & 51.3 & 49.5 & 119.6 & 109.5 \\
\hline 1 & 67.9 & 0.1 & -8.3 & 48.2 & 46.4 & 116.2 & 106.0 \\
\hline II & 68.3 & 0.3 & -8.0 & 54.4 & 52.5 & 123.0 & 112.8 \\
\hline
\end{tabular}

Col. 1: Col. 1 of Appendix Table 7 plus adjustments in Col. 3 of Appendix Table 8. Col. 2, 3: Col. 2 and 3 of Appendix Table 7 plus adjustments in Col. 5 of Appendix Table 8.

Col. 4, 5: Col. 4 and 5 of Appendix Table 7 plus adjustments in Col. 7 of Appendix Table 8.

\section{TRANSITION TO FINAL. PRODUCTS}

The three assumptions concerning the relative efficiency of the use of resources in munitions production and war construction are set forth in the text. Appendix Table 10 shows a sample calculation based on assumption $a$. The quarterly index in Column 1 is by graphic interpolation to annual totals, which allows for a two-thirds rise of the index from 1939 to the first half of 1943, some retardation in the relative rise from the third quarter of 1941 to the second quarter of 1942; and a more rapid rise thereafter. 
APPENDIX TABLE 10

Sample Calculation of War Outlay as a Final Product Component

Quarterly, 1939-1943

Assumption a

(dollar figures in billions, seasonally adjusted annual rates)

\begin{tabular}{|c|c|c|c|c|c|c|c|}
\hline $\begin{array}{c}\text { YEAR } \\
\text { AND } \\
\text { QUARTER }\end{array}$ & $\begin{array}{l}\text { RE } \\
\text { EPFicienC } \\
\text { Alunitions } \\
\text { \& uiar con-1 } \\
\text { struction } \\
\text { (1) }\end{array}$ & $\begin{array}{l}\text { ELATIVP } \\
\text { Y OF RESO } \\
\text { NonmA. } \\
\text { niriont } \\
(2)\end{array}$ & $\begin{array}{l}\text { Comp: } \\
\text { bined } \\
\text { (3) }\end{array}$ & $\begin{array}{l}\text { FAR } \\
\text { OUTRAY } \\
\text { IN } \\
\text { RESOURCE } \\
\text { UNITS } \\
\text { 1939 } \\
\text { VALUES } \\
\text { (4) }\end{array}$ & $\begin{array}{l}\text { EAR OUTLAY AS } \\
\text { FINAI PRODUCT } \\
{[(3) \times(4)]+100} \\
(5)\end{array}$ & $\begin{array}{l}\text { WAR } \\
\text { OUTLAY } \\
\text { CURRENT } \\
\text { PRCES } \\
(9)\end{array}$ & $\begin{array}{c}\text { IMPLICIT } \\
\text { PRICE } \\
\text { INDEX } \\
{[(6)+(5)] \times 100} \\
(7)\end{array}$ \\
\hline $\begin{array}{r}2939 \\
1 \\
\text { II } \\
111 \\
\text { IV }\end{array}$ & $\begin{array}{l}48 \\
48 \\
48 \\
48 \\
49\end{array}$ & $\begin{array}{r}100 \\
99 \\
100 \\
100 \\
101\end{array}$ & $\begin{array}{l}61 \\
61 \\
61 \\
61 \\
62\end{array}$ & $\begin{array}{l}1.35 \\
1.2 \\
1.3 \\
1.4 \\
1.5\end{array}$ & $\begin{array}{l}0.8 \\
0.7 \\
0.8 \\
0.8 \\
0.9\end{array}$ & 1.35 & 163 \\
\hline $\begin{array}{r}1940 \\
\text { I } \\
\text { II } \\
\text { III } \\
\text { IV }\end{array}$ & $\begin{array}{l}51 \\
50 \\
51 \\
51 \\
52\end{array}$ & $\begin{array}{l}102 \\
101 \\
102 \\
103 \\
103\end{array}$ & $\begin{array}{l}64 \\
63 \\
64 \\
64 \\
65\end{array}$ & $\begin{array}{l}2.42 \\
1.7 \\
2.0 \\
2.0 \\
4.0\end{array}$ & $\begin{array}{l}1.6 \\
1.1 \\
1.3 \\
1.3 \\
2.6\end{array}$ & 2.72 & 175 \\
\hline $\begin{array}{r}1941 \\
1 \\
11 \\
111 \\
\text { IV }\end{array}$ & $\begin{array}{l}56 \\
54 \\
55 \\
57 \\
59\end{array}$ & $\begin{array}{l}105 \\
104 \\
105 \\
105 \\
106\end{array}$ & $\begin{array}{l}68.5 \\
66.5 \\
67.5 \\
69 \\
71\end{array}$ & $\begin{array}{l}9.62 \\
6.3 \\
7.9 \\
10.4 \\
13.9\end{array}$ & $\begin{array}{l}6.6 \\
4.2 \\
5.3 \\
7.2 \\
9.9\end{array}$ & 12.50 & 188 \\
\hline $\begin{array}{r}1942 \\
1 \\
\text { II } \\
\text { III } \\
\text { IV }\end{array}$ & $\begin{array}{l}67 \\
61 \\
64 \\
69 \\
74\end{array}$ & $\begin{array}{l}105 \\
105 \\
105 \\
105 \\
105\end{array}$ & $\begin{array}{l}76.5 \\
72 \\
74 \\
78 \\
82\end{array}$ & $\begin{array}{l}33.47 \\
19.9 \\
29.2 \\
37.8 \\
47.0\end{array}$ & $\begin{array}{l}26.0 \\
14.3 \\
21.6 \\
29.5 \\
38.5\end{array}$ & 49.30 & 190 \\
\hline${ }_{11}^{1943}(1, b$ balf $)$ & $\begin{array}{l}80 \\
78 \\
82\end{array}$ & $\begin{array}{l}105 \\
105 \\
105\end{array}$ & $\begin{array}{l}86.5 \\
85 \\
88\end{array}$ & $\begin{array}{l}51.30 \\
48.2 \\
54.4\end{array}$ & $\begin{array}{l}44.4 \\
41.0 \\
47.9\end{array}$ & 81.05 & 182 \\
\hline
\end{tabular}

Col. 1 and 2: assumed, see text. Annual entries are direct averages of quarterly.

Col. 3: (Col. $1 \times 0.75)+($ Col. $2 \times 0.25)$. Annual entries: 100 (Col. $5 \div$ Col. 4).

Col. 4: From Appendix Table 9, Col. 4.

Col. 6: From Appendix Table 6, Col. 4.

Col. 7: Underlying calculation in Col. 5 carried to two decimal places.

The weights of the indexes in Columns 1 and 2 are based on the approximate proportions of the two components of war outlay (in 1939 prices in App. Table 9). The weights are held constant, since otherwise the proportion of nonmunitions in total war outlay could be calculated. But in general, variations in the proportions are relatively minor in quarterly totals in recent years.

The implicit prices derived in Column? are final product prices 
corresponding to the assumed relative efficiency of resources in munitions and war construction. They are obviously not relatives of actual prices in terms of 1939 as 100.

No quarterly entries are shown in Column 7 largely because the quarterly series in Column 6 was subjected to a different seasonal adjustment than the series upon which Columns 4 and 5 are based. As a result, the quarterly entries in Column 7 , if derived directly, would fluctuate erratically. It seemed unnecessary to make the minor adjustments, although they are easy and an implicit quarterly price index can be derived.

\section{APPENDIX TABLE 11}

War Outlay as a Final Product Component, Quarterly, 1939-1943

Assumptions $b$ and $c$ (dollar figures in billions, seasonally adjusted annual rates)

\begin{tabular}{|c|c|c|c|c|c|c|}
\hline \multirow[b]{2}{*}{$\begin{array}{c}\text { YEAE } \\
\text { AND } \\
\text { QUARTER }\end{array}$} & \multicolumn{3}{|c|}{ ASSUMPTION 6} & \multicolumn{3}{|c|}{ ASSUMPTION } \\
\hline & $\begin{array}{c}\text { Relatise } \\
\text { Effrciency } \\
\text { of Resources } \\
\text { in Wdr } \\
\text { Prodection } \\
\text { (1) }\end{array}$ & $\begin{array}{l}\text { War } \\
\text { Owlay } \\
\text { as Firal } \\
\text { Prodwct } \\
\text { (2) }\end{array}$ & $\begin{array}{c}\text { Price } \\
\text { Index } \\
\text { Implicit } \\
\text { in (2) } \\
\text { (3) }\end{array}$ & $\begin{array}{c}\text { Relative } \\
\text { Effciency } \\
\text { of Resources } \\
\text { in War } \\
\text { Prodetsion } \\
\text { (4) }\end{array}$ & $\begin{array}{c}\text { War } \\
\text { Oxtlay } \\
\text { as Final } \\
\text { Prodact } \\
\text { (5) }\end{array}$ & $\begin{array}{c}\text { Price } \\
\text { Index } \\
\text { Implici } \\
\text { in (5) } \\
\text { (6) }\end{array}$ \\
\hline 1939 & .72 & 1.0 & 138 & 84 & 1.1 & 119 \\
\hline I & 72 & 0.9 & & 83 & 1.0 & \\
\hline II & 72 & 0.9 & & 83.5 & 1.1 & \\
\hline III & 72 & 1.0 & & 83.5 & 1.2 & \\
\hline IV & 73 & 1.1 & & 84.5 & 1.3 & \\
\hline 1940 & 76 & 1.8 & 148 & 89 & 2.2 & 126 \\
\hline I & 74 & 1.3 & & 86 & 1.5 & \\
\hline II & 75 & 1.5 & & 88 & 1.8 & \\
\hline III & 76 & 1.5 & & 89.5 & 1.8 & \\
\hline IV & 79.5 & 3.1 & & 91 & 3.6 & \\
\hline 1941 & 82 & 7.9 & 158 & 96 & 9.5 & 134 \\
\hline I & 79 & 5.0 & & 93 & 5.9 & \\
\hline II & 81 & 6.4 & & 95 & 7.5 & \\
\hline III & 82.5 & 8.6 & & 97.5 & 10.1 & \\
\hline IV & 85 & 11.8 & & 100 & 13.9 & \\
\hline 1942 & 92 & 31.2 & 158 & 109 & 37.0 & 133 \\
\hline I & 87 & 17.3 & & 103 & 20.5 & \\
\hline II & 89 & 26.0 & & 106 & 30.95 & \\
\hline III & 94 & 35.5 & & 111 & 42.0 & \\
\hline IV & 98 & 46.1 & & 116 & 54.5 & \\
\hline 1943 (1st balf) & 105 & $\mathbf{5 4 . 0}$ & 150 & 124 & 63.8 & 127 \\
\hline I & 103 & 49.6 & & 121.5 & 58.6 & \\
\hline II & 107 & 58.3 & & 127 & 69.1 & \\
\hline
\end{tabular}

See notes to Appendix Table 10. Col. 1 and 4 in this table correspond to Col. 3 in Appendix Table 10; Col. 2 and 5 to Col. 5 of Appendix Fable 10; Col. 3 and 6 to Col. 7 of Appendix Table 10. 
Appendix Table 11 presents the more important steps in the calculations based upon assumptions $b$ and $c$. The quarterly interpolation of the efficiency indexes, as well as the movement of the annual totals, was established along lines similar to those adopted in the calculations based upon assumption a. This was in accord with the basic decision to vary the three assumptions only with respect to the levels of relative efficiency set for the first half of 1943 , but to make them the same with respect to the relative movement of the efficiency level from 1939 to 1943 .

\section{APpendix TAbLe 12}

Gross and Net National Product, Wartime Concept, Quarterly, 1939-1943 1939 Final Product Prices

Three Assumptions concerning the Relative Efficiency of Resources in Munitions and War Construction (billions of dollars, seasonally adjusted annual rates)

\begin{tabular}{|c|c|c|c|c|c|c|}
\hline \multirow{2}{*}{$\begin{array}{c}\text { YEAR } \\
\text { AND } \\
\text { QUARTER }\end{array}$} & \multicolumn{3}{|c|}{$\begin{array}{l}\text { GROSS NATIONAL PRODUCT } \\
\text { UNDER ASSU MPTION }\end{array}$} & \multicolumn{3}{|c|}{$\begin{array}{l}\text { NET NATIONAL PRODLCT } \\
\text { UNDER ASSLMPTIOS }\end{array}$} \\
\hline & (1) & $\stackrel{b}{(2)}$ & $\begin{array}{c}6 \\
(3)\end{array}$ & (4) & (s) & (6) \\
\hline 1939 & 78.8 & 79.0 & 79.1 & 71.6 & 71.8 & 71.9 \\
\hline 1 & 75.5 & 75.7 & 75.8 & 68.4 & 68.6 & 68.7 \\
\hline II & 77.3 & 77.4 & 77.6 & 70.1 & 70.2 & 70.4 \\
\hline III & 78.5 & 78.7 & 78.9 & 71.3 & 71.5 & 71.7 \\
\hline IV & 83.9 & 84.1 & 84.3 & 76.6 & 76.8 & $? 7.0$ \\
\hline 1940 & 86.2 & 86.4 & 86.8 & 78.8 & 79.0 & 79.4 \\
\hline I & 83.9 & 84.1 & 84.3 & 76.7 & 76.9 & 77.1 \\
\hline II & 84.7 & 84.9 & 85.2 & 77.3 & 77.5 & 77.8 \\
\hline III & 86.5 & 86.7 & 87.0 & 79.1 & 79.3 & 79.6 \\
\hline IV & 89.5 & 90.0 & 90.5 & 82.0 & 82.5 & 83.0 \\
\hline 1941 & 99.3 & 100.6 & 102.0 & 91.3 & 92.6 & 94.1 \\
\hline I & 94.3 & 95.1 & 96.0 & 86.6 & 87.4 & 88.3 \\
\hline II & 100.8 & 101.9 & 103.0 & 92.9 & 94.0 & 95.1 \\
\hline III & 102.0 & 103.4 & 104.9 & 93.9 & 95.3 & 96.8 \\
\hline IV & 100.3 & 102.2 & 104.3 & 92.0 & 93.9 & 96.0 \\
\hline 1942 & 104.5 & 109.7 & 115.5 & 95.2 & 100.4 & 106.2 \\
\hline I & 99.0 & 102.0 & 105.2 & 90.3 & 93.4 & 96.6 \\
\hline II & 103.9 & 108.3 & 113.25 & 94.7 & 99.1 & 104.1 \\
\hline III & 105.0 & 111.0 & 117.5 & 95.4 & 101.4 & 107.9 \\
\hline IV & 110.0 & 117.6 & 126.0 & 100.0 & 107.6 & 116.0 \\
\hline 1943 (1st balf) & 116.1 & 125.7 & 135.5 & 105.9 & 115.5 & 125.3 \\
\hline I & 112.4 & 121.0 & 130.0 & 102.2 & 110.8 & 119.8 \\
\hline II & 119.9 & 130.3 & $141: 1$ & 109.7 & 120.1 & 130.9 \\
\hline
\end{tabular}

Col. 1: Sum of Col. 1 and 2, Appendix Table 7, and Col. 5. Appendix Table 10.

Col. 2 and 3: Surn of Col. 1 and 2, Appendix Table 7, and Col. 2 and 5, Appendix Table 11 .

Col. 4, 5, 6: Correspond to $\mathrm{Col} .1,2,3$ after deduction of depreciation and depletion on both nonwar capital formation and war construction (see App. Table 7). 
The addition of war outlay, in terms of final output in accordance with the three assumptions, to flow of goods to consumers and nonwar capital formation, as derived in Appendix Table 7, yields three series of national product totals corresponding to the final products approach (App. Table 12).

In deriving national income or net national product totals (as distinct from gross national product), depreciation on war construction, as already calculated in Appendix Table 7, is subtracted from gross war outlay. By basing this item on the share of gross war outlay, we

\section{APPENDIX TABLE 13}

Gross and Net National Product, Wartime Concept, Quarterly, 1939-1943 1939 Final Product Prices

Disregarding the Relative Efficiency of the Use of Resources in Munitions and War Construction (dollar figures in billions, seasonally adjusted annual rates)

\begin{tabular}{|c|c|c|c|c|c|}
\hline $\begin{array}{l}\text { YEAX } \\
\text { AND }\end{array}$ & $\begin{array}{l}\text { PUICR INDEX } \\
\text { FOR WAR OUTAY }\end{array}$ & WAI & LAY & NATIO & obuct \\
\hline QUARTRR & $\begin{array}{c}(1939=100) \\
(1)\end{array}$ & $\begin{array}{c}\text { Gross } \\
\text { (2) }\end{array}$ & $\begin{array}{l}\text { Net } \\
(3)\end{array}$ & Gross & $\begin{array}{l}\mathrm{Net} \\
\text { (s) }\end{array}$ \\
\hline 1939 & 100 & 1.4 & 1.4 & 79.4 & 72.2 \\
\hline I & 98 & 1.2 & 1.2 & 76.0 & 68.9 \\
\hline II & 99 & 1.3 & 1.3 & 77.8 & 70.6 \\
\hline III & 101 & 1.4 & 1.4 & 79.1 & 71.9 \\
\hline $\mathbf{N}$ & 102 & 1.5 & 1.5 & 84.5 & 77.2 \\
\hline 1940 & 107 & 2.5 & 2.5 & 87.1 & 79.7 \\
\hline I & 104 & 1.6 & 1.6 & 84.3 & 77.1 \\
\hline II & 106 & 1.9 & 1.9 & 85.3 & 77.9 \\
\hline III & 108 & 2.3 & 2.3 & 87.5 & 80.1 \\
\hline IV & 110 & 4.3 & 4.2 & 91.2 & 83.7 \\
\hline 1941 & 114 & 10.9 & 10.6 & 103.6 & 95.6 \\
\hline 1 & 112 & 6.8 & 6.6 & 96.9 & 89.2 \\
\hline II & 114 & 8.8 & 8.5 & 104.3 & 96.4 \\
\hline III & 115 & 11.9 & 11.5 & 106.7 & 98.6 \\
\hline IV & 116 & 16.2 & 15.8 & 106.6 & 98.4 \\
\hline 1942 & 114 & 43.3 & 42.1 & 121.8 & 112.4 \\
\hline 1 & 116 & 23.9 & 23.3 & 108.6 & 100.0 \\
\hline II & 116 & 35.8 & 34.8 & 118.1 & 108.9 \\
\hline III & 114 & 50.1 & 48.8 & 125.6 & 116.0 \\
\hline IV & 112 & 63.3 & 61.7 & 134.8 & 124.9 \\
\hline 1943 (Ist balf) & 109 & 74.4 & 72.5 & 146.1 & 135.9 \\
\hline I & 110 & 68.2 & 66.4 & 139.6 & 129.4 \\
\hline II & 108 & 80.6 & 78.6 & 152.6 & 142.3 \\
\hline
\end{tabular}

Col. 1 derived from Appendix Tables 10, 11, and 12; Col. 2 and 3, by applying index in Col. 1 to current dollar value totals (App. Table 6); Col. 4 and 5, by adding Col. 2 and 3 to nonwar components from Appendix Table 7. 
could recalculate it in terms of final output as shown in Appendix Table 12, represented by war construction (as distinct from munitions). But it is not clear that the results would be a better approximation than the estimates used in Appendix Table 7; and in view of the necessarily arbitrary character of the underlying assumption as to length of life, recalculation seemed unwarranted.

Under the three assumptions, the implicit final product prices for munitions and war construction (and hence for war outlay) are not relatives in terms of 1939 as 100 . They could not be unless we disregarded differences in the relative efficiency of the use of resources in war production as compared with that in similar industries in peacetime. One may, therefore, ask what the temporal changes in final product prices of war outlay are, if relative efficiency is disregarded, and what the totals of war outlay and national product would be if adjusted for such price changes over time alone.

Appendix Table 13, Column 1, provides the key price index, derived from annual entries, which are in turn averages of the implicit price indexes in war outlay under the three assumptions in terms of 1939 as 100. These annual indexes are interpolated quarterly, largely again on the basis of the implicit quarterly price indexes under the three assumptions of Appendix Tables 10 and 11, smoothed to eliminate erratic fluctuations. The other columns in Appendix Table 13 are a matter of straightforward calculation from Column 1. 